\title{
Judge Optics on Environmental Dispute Objects, Expiration and Community Participation Principles In The Issuance of Environmental Document Processing On The Case of Kendeng*
}

\author{
Wahyu Nugroho, ${ }^{1}$ Ida Nurlinda, ${ }^{2}$ Bambang Daru Nugroho, ${ }^{3}$ Imamulhadi ${ }^{4}$ \\ Program Doktor Ilmu Hukum Universitas Padjadjaran \\ Jl. Banda Citarum Bandung West Java \\ E-mail: wahyunugroho@gmail.com
}

DOI: $\underline{10.15408 / j \text { ich.v5i2.7093 }}$

\begin{abstract}
:
Different ways of access to justice in Indonesia for minority or homogeneous communities in certain areas that utilize natural resources as part of their lives. Examples of this group are people in the mountains kendeng Rembang regency Central Java Province who mostly w ork as farmers and planters, against the Governor of Central Java and PT Semen Gresik (Persero) Tbk. Upon the issuance of Central Java Governor Decree No. 660.1/17/2012 on Environmental Permit for Mining and Construction of Cement Plant by PT Semen Gresik (Persero) Tbk. in Rembang District, Central Java Province dated June 7, 2012. Kendeng community took three levels of court lane, namely the State Administrative Court of Semarang, the State Administrative High Court of Surabaya and the Judicial Review Review. The case is interesting to examine and a good example of access to justice in Indonesia over the issue of environmental permit issuance, in the context of the development of environmental law studies and state administrative law, in particular judge optics as well as state administrative officials on the understanding and interpretation of the General Principles of Governance the Good (AUPB).
\end{abstract}

Keywords: Judge, Dispute, Environmental permit, Kendeng community, Court

\footnotetext{
* Received: July 30, 2017, Revised: August 24, 2017, Accepted: August 28, 2017.

1 Mahasiswa Program Doktor Ilmu Hukum Universitas Padjadjaran Angkatan 2016, bidang kajian Hukum Lingkung an, dan Dosen Tetap FH Universitas Sahid Jakarta.

${ }^{2}$ Ketua Promotor, GB FH Unpad, bidang hukum Lingkungan, Agraria dan Tata Ruang.

${ }^{3}$ Co-Promotor I, bidang kajian Hukum Adat, FH Universitas Padjadjaran Bandung.

${ }^{4}$ Co-Promotor I, bidang kajian Hukum Lingkungan, FH Universitas Padjadjaran.
} 


\title{
Optik Hakim Terhadap Objek Sengketa Izin Lingkungan, Kadaluarsa Dan Asas Partisipasi Masyarakat Dalam Proses Penerbitan Dokumen Lingkungan Hidup Atas Kasus Kendeng
}

\begin{abstract}
Abstrak:
Beragam cara akses terhadap keadilan (access to justice) di Indonesia bagi masyarakat minoritas atau homogen di daerah tertentu yang memanfaatkan sumber daya alam sebagai bagian dari kehidupannya. Contoh dari kelompok ini adalah masyarakat di pegunungan kendeng Kabupaten Rembang Provinsi Jawa Tengah yang sebagian besar bekerja sebagai petani dan pekebun, melawan Gubernur Jawa Tengah dan PT Semen Gresik (Persero) Tbk. atas terbitnya Surat Keputusan Gubernur Jawa Tengah Nomor 660.1/17 Tahun 2012 tentang Izin Lingkungan Kegiatan Penambangan dan Pembangunan Pabrik Semen oleh PT Semen Gresik (Persero) Tbk. di Kabupaten Rembang Provinsi Jawa Tengah tertanggal 7 Juni 2012. Masyarakat Kendeng menempuh tiga tingkatan jalur pengadilan, yakni Pengadilan Tata Usaha Negara Semarang, Pengadilan Tinggi Tata Usaha Negara Surabaya dan Peninjauan Kembali Mahkamah Agung. Kasus ini menarik untuk dikaji dan sebagai contoh yang baik akses terhadap keadilan di Indonesia atas sengketa penerbitan izin lingkungan, dalam rangka pengembangan kajian hukum lingkungan dan hukum administrasi negara, khususnya optik hakim maupun pejabat tata usaha negara terhadap pemahaman dan penafsiran atas Asas-asas Umum Pemerintahan yang Baik (AUPB).
\end{abstract}

Kata kunci: hakim, sengketa, izin lingkungan, masyarakat kendeng, pengadilan

\section{How to cite (turabian):}

Nugroho, Wahyu, Nurlinda, Ida, Nugroho, Bambang, and Hadi, Imamul. "Judge Optics on Environmental Dispute Dispute Objects, Expiration And Community Participation Principles In The Issuance Of Environmental Document Processing On The Case of Kendeng"JURNAL CITA HUKUM [Online], Volume 5 Number 2 (December 2017). 
Optik Hakim Terhadap Objek Sengketa Izin Lingkungan, Kadaluarsa dan Asas Partisipasi

Masyarakat Dalam Proses Penerbitan Dokumen Lingkungan Hidup atas Kasus Kendeng

\section{Pendahuluan}

Negara yang memiliki karakteristik keberagaman sistem hukum (legal system plurality) dalam satu sistem hukum nasional, sangatlah menarik untuk dicermati mulai dari pembentukan hukum (law making), perizinan (licencing), penerapan hukum (law implementing), hingga proses peradilan (judiciary process). Penyelenggara negara dalam konteks pemerintah (kekuasaan eksekutif) sebagai pemberi izin atas kegiatan usaha dan Peradilan (kekuasaan yudikatif) Tata Usaha Negara, sebagai kompetensi absolut atas objek sengketa administrasi lingkungan hidup membutuhkan optik dan pemahaman yang holistik-komprehensif, di tengah kondisi yang sangat beragam sistem hukum (legal pluralism) maupun masyarakat yang majemuk untuk diikat dalam satu sistem hukum nasional (unifikasi). ${ }^{5}$ Dalam kaitannya dengan kekuasaan eksekutif sebagai pemberi izin, keterlibatan masyarakat dalam proses penerbitan dokumen lingkungan hidup menjadi suatu hal yang penting, apabila pemerintah mengabaikan partisipasi masyarakat atas terbitnya dokumen-dokumen lingkungan hidup melalui Keputusan Pejabat Tata Usaha Negara, maka berpotensi diajukannya gugatan ke Pengadilan Tata Usaha Negara (PTUN).

Hubungan hukum antara pihak negara, investor dan masyarakat sekitar, pada prinsipnya atau tataran ideal terjadi keseimbangan kepentingan,

${ }^{5}$ Ditekankan oleh Ida Nurlinda bahwa dalam perspektif pluralisme hukum, sejatiny a dua atau lebih sistem hukum itu bersinergi dalam suatu sistem hukum nasional yang harmonis, bersinergi meskipun di sisi lain terjadi antinomi atas nilai-nilai y ang terkandung dalam kedua (atau lebih) sistem hukum tersebut. Pendekatan pembangunan yang eksploitatif terhadap sumber daya alam jelas bertentangan dengan prinsip-prinsip pelestarian hak ulayat yang berlaku pada masyarakat hukum adat. Lihat: Ida Nurlinda, Monograf Hukum Agraria; Membangun Pluralisme Hukum dalam Kerangka Unifikasi Hukum Agraria, Cet. I, Bandung: Pusat Studi Hukum Lingkung an dan Penataan Ruang Fakultas Hukum Universitas Padjadjaran \& Logoz Publishing, 2014, h. 3. Selanjutnya, contoh yang diberikan oleh Ida Nurlinda, yakni kebijakan pemerintah yang dituangkan dalam Peraturan Presiden No. 32 tahun 2011 tentang Masterplan Percepatan dan Perluasan Pembang unan Ekonomi Indonesia (MP3EI), sebag ai kebijakan y ang tidak memerhatikan kehidupan masyarakat hukum adat terjadi dalam kasus ini, yakni sengketa masyarakat adat Kendeng Kabupaten Rembang versus Gubernur Jawa Teng ah dan PT Semen Indonesia (Persero) Tbk., kebijakan MP3EI ternyata dijadikan sebagai dalih dalam bentuk eksepsi oleh Tergugat Intervensi II, yakni PT Semen Indonesia (Persero) Tbk., terkait perusahaan industri semen untuk melakukan ekspansi usaha agar dapat terealisasi. Industri semen y ang dikelola BUMN merupakan salah satu industri yang diandalkan untuk mendukung program MP3EI 2011-2025. Ditambahkan bahwa Tergug at Intervensi II telah ditetapkan sebagai Objek Vital Nasional Industri berdasarkan Keputusan Presiden No. 63 tahun 2014 jo Keputusan Menteri Perindustrian No. 620/2012 jo Keputusan Menteri Perindustrian No. 466 tahun 2014 jo Perpres MP3EI jo Sertifikat Objek Vital Nasional Sektor Industri. Lihat: Putusan Mahkamah Agung No. 99 PK/TUN/2016, h. 58.

Faculty of Sharia and Law UIN Syarif Hidayatullah Jakarta - 333 


\section{Wahyu Nugroho, Ida Nurlinda, Bambang Daru Nugroho, Imamulhadi}

tidak ada yang dominan dan saling berkompetisi satu sama lain. ${ }^{6}$ Namun, ketika terjadi suatu konflik baik vertikal maupun horizontal, masyarakat sekitar kegiatan usaha memiliki beragam cara untuk mendapatkan akses terhadap keadilan (access to justice) secara kolektif di Indonesia dalam pemanfaatan sumber daya alam. ${ }^{7}$ Beragam cara di antaranya adalah gerakan advokasi massa dan publikasi di media massa, kampanye lingkungan hidup, mediasi lingkungan dan sumber daya alam, pendudukan di sejumlah institusi pembuat kebijakan melalui demonstrasi dengan menampilkan teaterikal, penuntutan uang kompensasi dari pelaku usaha, jalur politik melalui penekanan ke sejumlah anggota dewan di lembaga legislatif sebagai perwakilan rakyat, hingga jalur prosedur formal melalui peradilan. Sejumlah teknik tersebut sangat tergantung kepada kekuatan kelompok massa yang dimilikinya dan memiliki keyakinan dengan cara tersebut, akan mendapatkan keadilan. Dalam konteks masyarakat petani kendeng, hampir semua upaya dilakukan, baik

${ }^{6}$ Dalam kaitannya dengan hal tersebut, Jimly Asshiddiqie memandang bahwa dalam sistem demokrasi modern dewasa ini, sistem kekuasaan dalam kehidupan bersama biasa dibedakan dalam tiga wilay ah atau domain, yaitu negara (state), pasar (market), dan masyarakat (civil society). Ketiga domain tersebut memiliki logika hukum sendiri-sendiri dan harus berjalan beriringan, saling mengendalikan satu sama lain dan tidak boleh dicampuradukkan atau mencampuri. Lihat: Jimly Asshiddiqie, Hukum Tata Negara \& Pilar-Pilar Demokrasi, Ed. 2, Cet. 2, Jakarta: Sinar Grafika, 2012, h. 133.

7 Adriaan Bedner, Seorang yang cukup familiar diantara para akademisi dan pe neliti socio-legal di Indonesia, merupakan Professor of Law and Society in Indonesia, Pengajar Mata Kuliah Hukum Indonesia di Leiden Law School, Leiden University (Associate Professor at the Van Vollenhoven Institute for Law, Governance and Society), dalam pengantar papernya "Akses terhadap Keadilan dan Penanganan Masalah Lingkungan", memberikan kategori sengketa lingkung an di Indonesia ke dalam tiga kelompok. Kelompok pertama, sengketa soal pemanfaatan sumber daya alam, dan biasanya antara warga dan perusahaan dengan peranan penting pemerintah sebagai pihak yang berwenang memberikan izin. Contohnya sengketa menyangkut pertambangan dan penebangan kayu. Fokus konflik tersebut biasanya adalah pengurangan dan/atau penolakan akses kepada sumber daya alam bagi penduduk setempat, tetapi kadangkadang jug a meny ang kut kebijakan perizinan negara. jenis lainny a adalah efek samping eksploitasi terhadap lingkungan dalam bentuk pencemaran dan kerusakan. Kelompok kedua, menyangkut masalah pencemaran atau kerusakan lingkungan di luar jenis sengketa kedua dalam dalam kategori pertama di atas. Sengketa pencemaran jenis ini biasany a berupa sengketa antara pelaku pencemaran (pollutor) dan komunitas lokal yang terkena dampak pencemaran, contoh konflik antara nelayan dan petambak udang dengan perusahaan minyak total di Kalimantan timur. Kelompok sengketa ketiga menyang kut konservasi alam. Di mana perselisihan terjadi antara warga (atau lembaga negara) yang melakukan kegiatan ekonomi yang berpotensi membahayakan konservasi alam di satu sisi, dan lembaga-lembaga negara atau pihak swasta di sisi lain. Selengkapny a lihat: Adriaan Bedner, dalam "Peng antar: Akses terhadap Keadilan dan Penang anan Masalah Lingkung an", Akses terhadap Keadilan; Perjuangan Masyarakat Miskin dan Kurang Beruntung untuk Menuntut Hak di Indonesia, Ed. I, Jakarta: HuMa; KITLV-Jakarta; Epistema Institute; Leiden: V an Vollenhoven Institute, 2011, h. 164-165.

334 - Jurnal Cita Hukum. Vol. 5 No. 2, December 2017. P-ISSN: 2356-1440. E-ISSN: 2502-230X 
litigasi maupun non litigasi (advokasi massa dan demonstrasi, publikasi isu hukum di sejumlah media massa, tekanan politik ke anggota DPRD dan pendudukan secara massal di sejumlah institusi pemerintahan dengan menampilkan teatrikal).

Secara teoritikal, kajian hukum administrasi negara dalam konteks pemerintah sebagai penyelenggara negara dan hakim lingkungan Peradilan Tata Usaha Negara di Indonesia pada prinsipnya memegang Asas-asas Umum Pemerintahan yang Baik (AUPB), yakni asas kepastian hukum, asas tertib penyelenggaraan Negara, asas kepentingan umum, asas keterbukaan, asas proporsionalitas, asas profesionalitas, dan asas akuntabilitas. ${ }^{8}$ Sejumlah asas tersebut terdapat dalam Undang-Undang Nomor 28 tahun 1999 tentang Penyelenggara Negara yang Bersih dan Bebas dari Korupsi, Kolusi, dan Nepotisme, ${ }^{9}$ kemudian juga Undang-Undang Nomor 30 tahun 2014 tentang Administrasi Pemerintahan. Keberlakuan kebijakan dan keputusan pejabat tata usaha negara yang efektif, dapat diterima dan memiliki nilai manfaat di masyarakat dapat diukur melalui transformasi asas umum pemerintahan yang baik ke dalam suatu keputusan tata usaha negara, asas tersebutlah sebagai batu uji dalam menjalankan pemerintahan yang baik (good governance).

Pejabat Tata Usaha Negara seringkali mengabaikan asas kearifan lokal dan partisipasi masyarakat dalam proses pengambilan keputusan pejabat Tata Usaha Negara (TUN). Apabila ditelisik ke belakang, hukum lingkungan pada

8 Terjadi perdebatan diantara pakar hukum administrasi negara terkait dengan bentuk "asas" dan "norma", di dalam asas-asas umum pemerintahan y ang baik. Dalam perkembang annya, asas atau prinsip tersebut telah menjadi norma hukum atau kaidah hukum. Untuk menjembatani terjadiny a perdebatan seputar bentuk asas atau norma, asas-asas umum pemerintahan yang baik jug a meng andung makna sebag ai asas atau sendi hukum, maka AUPB dapat dimaknai sebag ai asas hukum yang bahannya digali dan ditemukan dari unsur susila, didasarkan pada moral sebagai hukum riil, bertalian erat dengan etika, kesopanan, dan kepatutan berdasarkan norma yang berlaku. Namun, dalam perkembang anny a asas tersebut sang at dimung kinkan menjadi no rma dan diperluas tafsirannya oleh hakim PTUN. Lihat: Jazim Hamidi, Penerapan Asas-asas Umum Penyelenggaraan Pemerintahan yang layak (AUPB) di Lingkungan Peradilan Adm inistrasi Indonesia, Bandung: Citra Aditya Bakti, 1999, h. 48.

9 Asas-asas yang tercantum dalam UU No. 28 Tahun 1999 tersebut pada awalnya ditujukan untuk para penyelenggara Negara secara keseluruhan, berbeda deng an asas-asas umum pemerintahan yang baik yang sejak semula hanya ditujukam pada pemerintah dalam arti sempit, sesuai dengan istilah "bestuur" pada algemeen beginselen van behoorlijk bestuur, bukan regering atau overheid, yang mengandung arti pemerintah dalam arti luas. Namun, seiring dengan perjalanan waktu, asas-asas dalam UU No. 28 Tahun 1999 diakui dan diterapan di PTUN, yakni setelah adany a UU N. 9 Tahun 2004 tentang perubahan atas UU No. 5 tahun 1986 Tentang PTUN. Pasal 53 ay at (2), disebutkan "Keputusan Tata Usaha Negara yang digugat itu bertentangan dengan asasasas umum pemerintahan yang baik". Lihat: Ridwan HR., Hukum Administrasi Negara, Ed. Cet. 7, Jakarta: PT RajaGrafindo Persada, 2011, h. 242. 


\section{Wahyu Nugroho, Ida Nurlinda, Bambang Daru Nugroho, Imamulhadi}

prinsipnya ditempatkan sebagai instrumen pengendalian atau pencegahan dari adanya pencemaran dan/atau kerusakan lingkungan hidup di sejumlah sektor yang berkaitan dengan sumber daya alam. Namun, Keputusan Pejabat Tata Usaha Negara dalam bentuk Izin Lingkungan dan Amdal hanya sebagai formalitas belaka, tanpa melibatkan masyarakat sekitar dan mempertimbangkan pelestarian lingkungan. Bahkan, berbagai instrumen perizinan tersebut dijadikan sebagai alat (tool) untuk melanggengkan kekuasaan melalui tangan-tangan pemilik modal/investor. Akhirnya, terjadilah tarik-menarik antara kepentingan negara, dalam hal ini Pemerintah Provinsi Jawa Tengah dengan dalih pertumbuhan dan perkembangan investasi dan pembangunan ekonomi, dengan masyarakat sekitar pegunungan Kendeng yang mayoritas bermatapencaharian sebagai petani dengan menggantungkan kehidupannya pada lahan lokasi pembangunan pabrik semen (PT Semen Indonesia Tbk, Persero).

Dalam kasus Kendeng melalui putusan Peninjauan Kembali Mahkamah Agung Nomor 99 PK/TUN/2016 menarik untuk dikaji dan sebagai contoh yang baik akses terhadap keadilan di Indonesia atas sengketa penerbitan izin lingkungan, dalam rangka pengembangan kajian hukum lingkungan dan hukum administrasi negara, khususnya terhadap Asas-asas Umum Pemerintahan yang Baik (AUPB). Masyarakat petani Kendeng Kabupaten Rembang Provinsi Jaw a Tengah memperjuangkan hak-haknya dan beragam akses untuk mendapatkan keadilan, pada akhirnya memilih jalur peradilan sebagai alat utama melawan negara, yakni Pengadilan Tata Usaha Negara (PTUN) Semarang, Pengadilan Tinggi Tata Usaha Negara (PT TUN) Surabaya dan upaya hukum paling akhir dalam sistem peradilan di Indonesia, yakni Peninjauan Kembali. Pengadilan Tingkat Pertama memberikan pertimbangan dan berkesimpulan batas pengajuan gugatan telah melebihi waktu 90 (sembilan puluh) hari atau telah daluwarsa dan gugatan prematur atas dasar belum ada tanggapan baik lisan mapun tertulis keberatan yang diajukan oleh warga kendeng kepada Gubernur Jawa Tengah, sehingga putusannya tidak dapat diterima.

Sementara Pengadilan Tingkat Banding justru memperkuat putusan tingkat pertama, melakukan kebohongan publik dan tidak menggali fakta-fakta di lapangan. Perjalanan yang meletihkan namun tidak mengurangi semangat para warga kendeng akhirnya membuahkan hasil setelah mengajukan upaya hukum paling akhir Peninjauan Kembali ke Mahkamah Agung. Novum yang diajukan dalam bentuk tiket pesawat garuda, boarding pass dan surat pernyataan terbang oleh pihak ticketing garuda. Majelis hakim Peninjauan Kembali hampir menyanggah semua pertimbangan maupun kesimpulan hakim 336 - Jurnal Cita Hukum. Vol. 5 No. 2, December 2017. P-ISSN: 2356-1440. E-ISSN: 2502-230X 
tingkat pertama dan banding. Sebaliknya, dalil-dalil pemohon (warga kendeng) diperkuat oleh majelis hakim Peninjauan Kembali melalui optik yang holistik dan penggalian terhadap fakta-fakta di lapangan, dan akhirnya dikabulkan untuk seluruhnya permohonan pemohon.

Uraian peristiwa dan perjalanan semua tingkat peradilan tersebut, sebagai dasar untuk melakukan kajian kritis atas optik hakim terhadap obyek sengketa izin lingkungan, sebagai bagian dari keputusan pejabat tata usaha negara yang memiliki karakter khusus. Selain itu, pemahaman dan tafsir baik hakim maupun pejabat TUN terhadap obyek gugatan TUN di bidang lingkungan hidup, masa tenggang atau kadaluarsa dalam pengajuan gugatan, tafsir atas AUPB, dan asas partisipasi masyarakat dalam proses penerbitan instrumen perizinan lingkungan hidup menjadi bagian dari telaah ini. Bukan sekedar mengumumkan dalam artian publisitas belaka, melainkan juga meminta masyarakat untuk melakukan tanggapan, penilaian dan pertimbangan-pertimbangan, dengan mendasarkan kepada kearifan lokal, dampak lingkungan, akses pengelolaan potensi sumber daya alam, dan asas musyawarah mufakat.

\section{Permasalahan}

Hakim Pengadilan Tata Usaha Negara sebagai kompetensi absolut dalam menyelesaikan sengketa keputusan tata usaha negara oleh Pejabat Tata Usaha Negara dengan masyarakat, dipandang perlu membedakan obyek sengketa tata usaha negara biasa dengan obyek sengketa tata usaha negara bidang lingkungan hidup. Keputusan Pejabat Tata Usaha Negara terkait dokumen lingkungan hidup lebih memerhatikan dampak lingkungan dalam jangka panjang, asas kearifan lokal, selain memerhatikan asas partisipasi masyarakat mulai dari proses awal hingga penerbitan keputusan tata usaha negara. suatu keputusan pejabat tata usaha negara yang tidak melibatkan partisipasi masyarakat, terlebih lagi persoalan lingkungan hidup dan akses sumber daya alam oleh penduduk lokal, akan berakibat fatal di kemudian hari. Hakim harus memiliki paradigma hukum yang holistik, ${ }^{10}$ memandang

10 Paradigma hukum yang holistik disebut sebagai cara pandang yang utuh dalam memahami gejala-gejala di jagat raya, di mana manusia menjadi bagian dari unsur jagat raya tersebut, manusia memandang secara holistik sangatlah dibutuhkan di abad 21, seiring dengan kompleksitas permasalahan hukum lingkungan dan sumber day a alam di segala sektor. Sebagai lawan kata dari holistik yaitu cara pandang yang fragmentaris dan parsial. Fragmentaris diartikan sebag ai pengkotak-kotakan atau memandang sepotong-sepotong terhadap suatu obyek, sementara 


\section{Wahyu Nugroho, Ida Nurlinda, Bambang Daru Nugroho, Imamulhadi}

lingkungan hidup menjadi bagian dari kehidupannya dan menjadi tugas manusia untuk menjaga kelestarian lingkungan. Kesalahan cara pandang hakim dalam memeriksa perkara lingkungan hidup dari segi administrasi, akan mempengaruhi pola pikir di kemudian hari dalam memberikan penafsiran, pertimbangan-pertimbangan dan kesimpulan hingga putusan. Oleh karena itu, di sini penulis menguraikan permasalahan yang akan dibahas dalam tulisan ini adalah: Bagaimana optik hakim dalam memahami objek sengketa izin lingkungan dan penggalian kebenaran atas fakta-fakta di lapangan pada masyarakat Kendeng? Bagaimana penerapan hakim dalam menafsirkan ihwal kadaluwarsa dan asas partisipasi masyarakat dalam proses penerbitan dokumen lingkungan hidup?.

\section{Filosofi Hak Penguasaan Negara Atas Sumber Daya Alam}

Dalam sebuah negara demokrasi yang ideal, penyelenggaraan kekuasaan berpedoman kepada apa yang dikehendaki rakyat sebagai pemegang kedaulatan tertinggi dan memiliki orientasi untuk memberikan kesejahteraan rakyat. Penyelenggara negara yang berada dalam lingkaran legislatif (anggota lembaga perwakilan) dan eksekutif (presiden dan wakil presiden) pada hakikatnya merupakan kontrak sosial antara rakyat dengan penyelenggara negara dan mandat rakyat melalui proses-proses pemilihan umum dan atau pemilihan kepala daerah. Melalui kekuasaanlah, segala apa yang diinginkan oleh eksekutif dan yudikatif senantiasa harus memiliki kesamaan dengan apa yang dikehendaki oleh rakyatnya.

Menurut Van Apeldoorn, kata penguasaan haruslah dimaknai sebagai suatu hak yang didasarkan atas suatu kekuasaan (macht) yang teratur oleh hukum berdasarkan kesusilaan (zadelijkheid, moral).11 Dengan demikian, kekuasaan yang diatur oleh hukum dijadikan dasar hak untuk mengatur oleh negara. Dalam hal ini, negara harus dilihat sebagai subjek hukum yang mempunyai kewajiban dan tanggung jawab yang bersifat publik. Sedangkan menurut Bagir Manan, ketentuan Pasal 33 ayat (3) UUD 1945 merupakan dasar konstitusional hak menguasai negara (HMN) atas bumi, air, dan kekuayaan alam yang terkandung didalamnya. "Hak menguasai negara" yang didasarkan atas konstitusi tersebut, "dipergunakan untuk sebesar-besarnya kemakmuran

parsial diartikan sebagian. Cara pandang yang seperti itu akan melahirkan cara berhukum yang hanya mengeja teks hukum, tanpa menggali tingkat kedalaman suatu teks hukum.

11 Van Apeldoorn, dalam naskah aslinya berjudul "Inleiding tot de Studie van het

Nederlandse Recht", terjemahan oleh Oetarid Sadino, Pengantar Ilmu Hukum, Jakarta: Pradnya Paramita, h. 22.

338 - Jurnal Cita Hukum. Vol. 5 No. 2, December 2017. P-ISSN: 2356-1440. E-ISSN: 2502-230X 
Optik Hakim Terhadap Objek Sengketa Izin Lingkungan, Kadaluarsa dan Asas Partisipasi Masyarakat Dalam Proses Penerbitan Dokumen Lingkungan Hidup atas Kasus Kendeng

rakyat". Kedua kaidah itu tidak dapat dipisahkan satu sama lainnya, keduanya merupakan satu kesatuan yang sistematik. Jadi, HMN lebih bersifat instrumental, sedangkan dipergunakan untuk sebesar-besarnya kemakmuran rakyat merupakan suatu tujuan (objectives). Untuk itu, negara mempunyai kew ajiban sebagai berikut: ${ }^{12}$

(1) Segala bentuk pemanfaatan (bumi dan air) serta hasil yang didapat (kekayaan alam), harus secara nyata meningkatkan kemakmuran dan kesejahteraan masyarakat;

(2) Melindungi dan menjamin segala hak-hak rakyat yang terdapat didalam atau di atas bumi, air dan berbagai kekayaan alam tertentu yang dapat dihasiilkan secara langsung atau dinikmati langsung oleh rakyat;

(3) Mencegah segala tindakan dari pihak manapun yang akan menyebabkan rakyat tidak mempunyai kesempatan atau akan kehilangan haknya dalam menikmati kekayaan alam.

Upaya eksploitasi sumber daya alam yang bijaksana adalah kunci dalam pengelolaan, pengambilan, dan pemanfaatannya agar tidak terjadi kerusakan lingkungan. Dalam konteks "hak penguasaan negara atas sumber daya alam" menurut Juniarso Ridwan melekat di dalamnya "kewajiban negara" untuk melindungi, melestarikan, dan memulihkan lingkungan hidup secara utuh dan menyeluruh. ${ }^{13}$ Inilah yang dimaksud dengan substansi pokok dari kedua hal, yakni: pertama, pemanfaatan sumber daya alam (eksploitasi), untuk sebesar-besarnya bagi kemakmuran rakyat; dan kedua, perlindungan, pemeliharaan, dan pengendalian alam (lingkungan) dari kerusakan dan/pencemaran. Artinya, aktivitas pembangunan pada umumnya bernuansa pemanfaatan sumber daya alam khususnya, harus diarahkan ke dalam kerangka kepentingan sekarang dan masa yang akan datang.

\section{Instrumen Perizinan Lingkungan Hidup}

Instrumen keterpaduan adalah instrumen yang diatur di dalam Undang-Undang No. 32 tahun 2009 Tentang Perlindungan dan Pengelolaan Lingkungan Hidup sebagai pedoman dalam penerbitan, pelaksanaan dan

\footnotetext{
12 Bagir Manan, Beberapa Catatan atas Rancangan Undang-Undang tentang Minyak dan Gas Bumi, Bandung: FH-Unpad, 1999, h. 1-2.

13 Juniarso Ridwan dan Achmad Sodik, Hukum Tata Ruang dalam Konsep Kebijakan Otonomi Daerah, Cet. 3, Bandung: Penerbit Nuansa, 2016, h. 69.
}

Faculty of Sharia and Law UIN Syarif Hidayatullah Jakarta - 339 


\section{Wahyu Nugroho, Ida Nurlinda, Bambang Daru Nugroho, Imamulhadi}

pengawasan izin bidang lingkungan hidup. Selain itu, UU 32/2009 juga disebut sebagai undang-undang payung (umbrella lex) atau perundang-undangan lingkungan hidup yang umum (general environmental law). Instrumen-instrumen tersebut memuat hal-hal yang utuh dan menyeluruh berkaitan dengan perlindungan dan pengelolaan lingkungan hidup. Beberapa instrumen adalah sebagai berikut:

\section{a. Kajian Lingkungan Hidup Strategis (KLHS)}

KLHS merupakan instrumen untuk mengintegrasikan pertimbangan lingkungan dalam pengambilan keputusan pada tahap kebijakan, rencana atau program untuk menjamin pembangunan berkelanjutan sedini mungkin. Berdasarkan definisi tersebut dan mempertimbangkan kesesuaian dengan kebutuhan instrumen pengelolaan lingkungan di Indonesia, maka definisi KLHS yang digunakan di Indonesia adalah proses sistematis dan komprehensif untuk mengevaluasi dampak lingkungan dengan mempertimbangkan aspek sosial-ekonomi serta prinsip-prinsip keberlanjutan dari usulan kebijakan, rencana, atau program pembangunan. KLHS adalah rangkaian analisis yang sistematis, menyeluruh, dan partisipatif untuk memastikan bahwa prinsip pembangunan berkelanjutan telah menjadi dasar dan terintegrasi dalam pembangunan suatu wilayah dan atau kebijakan, rencana, dan atau program.

\section{b. Tata Ruang}

Penataan ruang merupakan proses yang meliputi perencanaan, pemanfaatan dan pengendalian pemanfaatan ruang. Mengacu pada pengertian ini, penataan ruang semestinya menjadi wadah bagi kegiatan pembangunan yang memanfaatkan ruang, sehingga penataan ruang dapat menjadi acuan dan pedoman bagi perumusan kebijakan pembangunan sektor dan daerah.

Keterkaitan perencanaan tata ruang dan pembangunan berkelanjutan merupakan suatu aksioma, yakni sesuatu yang sudah pasti dan tidak memerlukan pembuktian serta telah diketahui oleh masyarakat umum. Meskipun aksiomatik, namun kita memperoleh pemahaman tambahan dari kenyataan tersebut, yakni praktik pelaksanaan sistem perencanaan tata ruang yang memengaruhi tujuan akhir pembangunan berkelanjutan. Jika pelaksanaan sistem perencanaan tata ruang berjalan dengan baik, maka tujuan pembangunan berkelanjutan akan tercapai, demikian pula sebaliknya.

\section{c. Baku Mutu Lingkungan}

Baku mutu lingkungan merupakan instrumen teknis untuk menentukan terjadinya pencemaran lingkungan hidup akibat pelaksanaan 340 - Jurnal Cita Hukum. Vol. 5 No. 2, December 2017. P-ISSN: 2356-1440. E-ISSN: 2502-230X 
Optik Hakim Terhadap Objek Sengketa Izin Lingkungan, Kadaluarsa dan Asas Partisipasi

suatu izin usaha dan atau kegiatan. Menurut Daud Silalahi, agar lingkungan hidup mampu mendukung kegiatan pembangunan yang berkesinambungan (berkelanjutan), usaha untuk memelihara dan mengembangkan mutu lingkungan hidup Indonesia penting.

Gagasan menetapkan suatu patokan atau baku mutu lingkungan hidup sebagai bagian dari hukum lingkungan Indonesia, pertama kali dikemukakan oleh Mochtar Kusumaatmadja pada Seminar Nasional Pengelolaan Lingkungan Hidup dan Pembangunan Nasional pada tahun 1972 di Unpad Bandung antara lain: ${ }^{14}$

Mengingat bahwa negara kita sebagaimana juga kebanyakan negara yang sedang berkembang, me miliki tole ransi yang lebih be sar te rhadap pencemaran lingkungan, suatu cara yang baik untuk mengkonkretkan atau sebenarnya mengkualifikasikan tujuan-tujuan sosial, dalam hal ini perlindungan lingkungan, dalam rencana-rencana pe mbangunan adalah untuk menetapkan atau merumuskan ukuran-ukuran minimum bertalian dengan lingkungan (minimum environment standards) untuk setiap sektor kehidupan dan usaha pembangunan kita....

Selain itu, untuk tujuan pengintegrasian faktor perlindungan hidup ke dalam perencanaan pembangunan, membantu orang untuk memikirkan distribusi yang lebih merata dari hasil usaha pembangunan dan tidak terlalu terpesona oleh sasaran pertumbuhan GNP, minimum environment standards, itu diharapkan mempunyai efek sebagai "pedoman" bagi usaha nasional secara menyeluruh. ${ }^{15}$

\section{Rencana Perlindungan dan Pengelolaan Lingkungan Hidup (RPPLH)}

Perencanaan perlindungan dan pengelolaan lingkungan hidup terdiri dari tiga tahap, yakni inventarisasi lingkungan hidup, penetapan wilayah ekoregion, serta penyusunan RPPLH. Penyusunan RPPLH dilakukan berdasarkan hasil inventarisasi lingkungan. Untuk RPPLH nasional, didasarkan pada hasil inventarisasi lingkungan hidup tingkat nasional, sedangkan RPPLH tingkat provinsi disusun berdasarkan RPPLH tingkat nasional, inventarisasi lingkungan tingkat pulau/kepulauan dan inventarisasi tingkat region. RPPLH Kabupaten/Kota didasarkan pada RPPLH Provinsi, inventarisasi tingkat

\footnotetext{
${ }_{14}$ M. Daud Silalahi, Hukum Lingkungan Dalam Sistem Penegakan Hukum Lingkungan Indonesia, Bandung: Alumni, 2001, h. 116.

${ }^{15}$ M. Daud Silalahi, Hukum Lingkungan Dalam Sistem Penegakan Hukum Lingkungan Indonesia, h. 117.
}

Faculty of Sharia and Law UIN Syarif Hidayatullah Jakarta - 341 


\section{Wahyu Nugroho, Ida Nurlinda, Bambang Daru Nugroho, Imamulhadi}

pulau/kepulauan dan inventarisasi tingkat ekoregion. RPPLH disusun berdasarkan tingkat kewenangannya masing-masing disusun oleh Menteri, Gubernur, serta Bupati/Walikota.

Pasal 10 ayat (3) UU No. 32 Tahun 2009, RPPLH yang telah disusun diatur dalam "peraturan pemerintah untuk RPPLH nasional, peraturan daerah provinsi untuk RPPLH provinsi, dan peraturan daerah kabupaten/kota untuk RPPLH Kabupaten/Kota". Pengaturan RPPLH dalam peratur an perundangundangan, berarti RPPLH merupakan norma umum yang berlaku sebagai hukum positif dalam rangka penyelenggaraan perlindungan dan pengelolaan lingkungan hidup.

Materi muatan dalam RPPLH, sebagaimana dinyatakan dalam ayat (4), antara lain:

a. Pemanfaatan dan/atau pencadangan sumber daya alam;

b. Pemeliharaan dan perlindungan kualitas dan/atau fungsi lingkungan hidup;

c. Pengendalian, pemantauan, serta pendayagunaan dan pelestarian sumber daya alam; dan

d. Adaptasi dan mitigasi terhadap perubahan iklim.

Ruang lingkup berdasarkan materi muatan tersebut menjadi panduan untuk diintegrasikan ke dalam perizinan UU Sektoral, dalam konteks ini perizinan di sektor pertambangan melalui UU No. 4 Tahun 2009 tentang Pertambangan Mineral dan Batubara, beserta peraturan pelaksanaan dan peraturan daerah.

\section{Analisis Mengenai Dampak Lingkungan (Amdal)}

Ketentuan umum Analisis Mengenai Dampak Lingkungan dapat ditemukan di dalam Pasal 22 Paragraf 5 Undang-Undang No. 32 Tahun 2009 tentang Perlindungan dan Pengelolaan Lingkungan Hidup adalah kajian mengenai dampak penting suatu usaha dan/atau kegiatan yang direncanakan pada lingkungan hidup yang diperlukan bagi proses pengambilan keputusan tentang penyelenggaraan usaha dan/atau kegiatan. Pasal 33 dari UU PPLH menyatakan bahwa ketentuan lebih lanjut mengenai amdal sebagaimana 
Optik Hakim Terhadap Objek Sengketa Izin Lingkungan, Kadaluarsa dan Asas Partisipasi Masyarakat Dalam Proses Penerbitan Dokumen Lingkungan Hidup atas Kasus Kendeng

dimaksud dalam Pasal 22 sampai dengan Pasal 32 diatur dalam Peraturan Pemerintah. ${ }^{16}$

Di dalam Pasal 4 Peraturan Pemerintah No. 27 Tahun 2012 Tentang Izin Lingkungan, Amdal disusun oleh pemrakarsa pada tahap perencanaan suatu usaha atau kegiatan yang w ajib sesuai dengan rencana tata ruang, apabila tidak sesuai dengan rencana tata ruang, maka dokumen Amdal tidak dapat dinilai dan wajib dikembalikan kepada pemrakarsa.

Dalam penyusunan dokumen lingkungan hidup yang lebih teknis, diatur di dalam Peraturan Menteri. ${ }^{17}$ Sedangkan khusus mengenai pengikutsertaan masyarakat dalam penyusunan Amdal, sebagaimana dinyatakan dalam Pasal 9 ayat (1) PP No. 27 Tahun 2012, yakni: a. masyarakat yang terkena dampak; b. pemerhati lingkungan hidup; c. dan atau yang terpengaruh atas segala bentuk keputusan dalam proses amdal, diatur lebih teknis di dalam Peraturan Menteri berkaitan dengan tata cara pengikutsertaan masyarakat dalam penyusunan amdal. ${ }^{18}$

Sistem Amdal di Indonesia telah ada sekitar 20 tahun lamanya. Pada akhir tahun 2003, Kementerian Lingkungan Hidup (KLH) meluncurkan suatu tahap lanjutan dari reformasi sistem kajian dampak lingkungan. Revitalisasi

16 Peraturan Pemerintah yang dimaksud adalah Peraturan Pemerintah No. 27 Tahun 2012 tentang Izin Ling kung an. PP tersebut sebag ai perubahan dari PP No. 27 tahun 1999 tentang Analisis Mengenai Dampak Lingkungan. Di dalam Pasal 74 PP No. 27 tahun 2012 te ntang Izin Lingkung an dinay atakan: Pada saat Peraturan Pemerintah ini mulai berlaku, Peraturan Pemerintah Nomor 27 Tahun 1999 tentang Analisis Mengenai Dampak Lingkung an Hidup (Lembaran Negara Republik Indonesia Tahun 1999 Nomor 59, Tambahan Lembaran Negara Republik Indonesia Nomor 3838) dicabut dan diny atakan tidak berlaku.

17 Peraturan Menteri y ang dimaksud adalah Peraturan Menteri Negara Lingkung an Hidup Republik Indonesia Nomor 16 tahun 2012 tentang Pedoman Penyusunan Dokumen Lingkungan Hidup, sebagai pelaksana dari Pasal 6 dan Pasal 16 PP No. 27 Tahun 2012 tentang Izin Ling kungan. Dalam Peraturan Menteri ini, Pasal 10 menyatakan: Pada saat Peraturan Menteri ini mulai berlaku: a). Peraturan Menteri Negara Lingkungan Hidup Nomor 08 Tahun 2006 tentang Pedo man Peny usunan Dokumen Analisis Mengenai Dampak Lingkung an Hidup; dan b). Peraturan Menteri Negara Lingkung an Hidup Nomor 13 Tahun 2010 tentang Upay a Pengelolaan Lingkung an Hidup dan Upaya Pemantauan Lingkungan Hidup dan Surat Penyataan Kesanggupan Pengelo laan dan Pemantauan Lingkungan Hidup, dic abut dan diny atakan tidak berlaku.

18 Peraturan Menteri dimaksud adalah Peraturan Menteri Negara Lingkungan Hidup Republik Indonesia No. 17 Tahun 2012 tentang Pedoman Keterlibatan Masyarakat Dalam Proses Analisis Dampak Lingkungan Hidup dan Izin Lingkungan, untuk melaksanakan Pasal 9 ayat (6) dan Pasal 52 PP No. 27 Tahun 2012. Adapun Muatan Pedoman keterlibatan masyarakat dalam proses Analisis Mengenai Dampak Lingkungan dan Izin Lingkungan dinyatakan dalam Pasal 4 Permen. Lingkungan Hidup No. 17 Tahun 2012: a. pendahuluan; b. tata cara pengikutsertaan masy arakat dalam proses analisis mengenai dampak lingkungan; dan c. tata cara pengikutsertaan masy arakat dalam proses izin lingkungan.

Faculty of Sharia and Law UIN Syarif Hidayatullah Jakarta - 343 


\section{Wahyu Nugroho, Ida Nurlinda, Bambang Daru Nugroho, Imamulhadi}

amdal bertujuan untuk menjawab berbagai tantangan. Bank Dunia menyediakan bantuan dari revitalisasi Amdal melalui riset untuk mengadaptasikan peraturan lingkungan hidup yang berubah. Berdasarkan hasil studi yang dilakukan oleh Helmi, ${ }^{19}$ di tingkat Provinsi Jawa Barat dan Kalimantan Timur dengan melihat berbagai sistem Amdal ada pada saat ini dapat divariasikan untuk memungkinkan ada berbagai perbedaan di dalam prioritas lingkungan yang ada dari satu daerah ke daerah lain atas praktik Amdal yang baik.

\section{Izin Lingkungan}

Amdal dan UKL-UPL merupakan salah satu syarat untuk mendapatkan Izin Lingkungan. ${ }^{20}$ Pada dasarnya, proses penilaian Amdal atau pemeriksaan UKL-UPL merupakan satu-kesatuan dengan proses permohonan dan penerbitan izin lingkungan. Dengan dimasukkannya Amdal dan UKL-UPL dalam proses perencanaan usaha dan/atau kegiatan, maka Menteri, Gubernur, atau Bupati/Walikota sesuai dengan kewenangannya mendapatkan informasi yang luas dan mendalam terkait dengan dampak lingkungan yang mungkin terjadi dari suatu rencana usaha dan/atau kegiatan tersebut dan langkahlangkah pengendaliannya, baik dari aspek teknologi, sosial, dan keagamaan. ${ }^{21}$

Tujuan diterbitkannya izin lingkungan antara lain untuk memberikan perlindungan terhadap lingkungan hidup yang lestari dan berkelanjutan, meningkatkan upaya pengendalian usaha dan/atau kegiatan yang berdampak negatif pada lingkungan hidup. Di samping itu juga untuk memberikan kejelasan prosedur, mekanisme dan koordinasi antar instansi dalam penyelenggaraan perizinan untuk usaha dan/atau kegiatan bagi setiap pelaku usaha. ${ }^{22}$

${ }^{19}$ Helmi, Hukum Perizinan Lingkungan Hidup, Cet. I, Jakarta: Sinar Grafika, 2012, h. 132.

20 Dalam Pasal 36 UU No. 32 Tahun 2009 tentang Perlindungan dan Pengelolaan Lingkung an Hidup, meng atur tentang izin lingkungan. Diny atakan: ay at (1) Setiap usaha dan/atau kegiatan yang wajib memiliki amdal atau UKL-UPL wajib memiliki izin lingkungan. ay at (2) Izin lingkungan sebagaimana dimaksud pada ayat (1) diterbitkan berdasarkan keputusan kelayakan lingkungan hidup sebagaimana dimaksud dalam Pasal 31 atau rekomendasi UKL-UPL. Ayat (3) Izin lingkungan sebagaimana dimaksud pada ayat (1) wajib mencantumkan persyaratan yang dimuat dalam keputusan kelayakan lingkungan hidup atau rekomendasi UKL-UPL. Ay at (4) Izin lingkungan diterbitkan oleh Menteri, Gubernur, atau Bupati/Walikota sesuai dengan kewenangannya.

${ }^{21}$ Bachrul Amiq, Penerapan Sanksi Administrasi dalam Hukum Lingkungan, Cet. I, Yogyakarta: Laksbang Mediatama, 2013, h. 86.

22 Bachrul Amiq, Penerapan Sanksi Administrasi dalam Hukum Lingkungan, h. 87.

344 - Jurnal Cita Hukum. Vol. 5 No. 2, December 2017. P-ISSN: 2356-1440. E-ISSN: 2502-230X 
Optik Hakim Terhadap Objek Sengketa Izin Lingkungan, Kadaluarsa dan Asas Partisipasi Masyarakat Dalam Proses Penerbitan Dokumen Lingkungan Hidup atas Kasus Kendeng

\section{Partisipasi Masyarakat Dalam Penerbitan Instrumen Perizinan Lingkungan Hidup}

Dalam kegiatan usaha penambangan atau sektor lainnya, proses-proses penerbitan sejumlah instrumen perizinan lingkungan hidup hingga pengumuman keluarnya surat keputusan Pejabat Tata Usaha Negara, perlu mempertimbangkan masyarakat sebagai pihak yang terkena dampak lingkungan. Badan usaha yang selalu berhubungan dengan negara, dalam hal ini pemerintah sebagai pihak pemberi izin usaha, hendaknya memerhatikan faktor-faktor sosial, ekonomi dan budaya setempat. Kelemahan pembangunan ekonomi di negara berkembang saat ini yaitu tidak ada keterlibatan dari masyarakat dalam proses penerbitan izin usaha, dokumen-dokumen lingkungan. Negara tidak memandang atau mempertimbangkan suatu komunitas lokal, masyarakat adat atau masyarakat yang masih tradisional berada di kawasan pertambangan. Komunitas lokal atau masyarakat yang masih tradisional memanfaatkan potensi alam sebagai kehidupannya. Dalam hal ini terjadi pada masyarakat Kendeng Kabupaten Rembang yang bekerja sebagai petani atau pekebun, tergeser hak-hak ekonomi, sosial, budaya dan hak lingkungan karena ditetapkan sebagai kawasan pertambangan semen .

Berdasarkan Pasal 70 Undang-Undang No. 32 Tahun 2009 tentang Perlindungan dan Pengelolaan Lingkungan Hidup, diatur mengenai peran serta masyarakat dalam bentuk: a). pengawasan sosial; b). pemberian saran, pendapat, usul, keberatan, pengaduan; dan/atau c). penyampaian informasi dan/atau laporan. Sementara peran masyarakat dilakukan untuk: a). meningkatkan kepedulian dalam perlindungan dan pengelolaan lingkungan hidup; b). meningkatkan kemandirian, keberdayaan masyarakat, dan kemitraan; c). menumbuhkembangkan kemampuan dan kepeloporan masyarakat; d). menumbuhkembangkan ketanggapsegeraan masyarakat untuk melakukan pengawasan sosial; dan e). mengembangkan dan menjaga budaya dan kearifan lokal dalam rangka pelestarian fungsi lingkungan hidup.

Dalam kaitannya dengan proses penerbitan izin lingkungan dan Amdal berdasarkan Pasal 9 ayat (6) dan Pasal 52 Peraturan Pemerintah Nomor 27 tahun 2012 tentang Izin Lingkungan, perlu melibatkan peran serta masyarakat. Pasal-pasal tersebut secara teknis operasional ditindaklanjuti oleh menteri lingkungan hidup melalui Peraturan Menteri Negara Lingkungan Hidup Republik Indonesia Nomor 17 tahun 2012 tentang Pedoman Keterlibatan Masyarakat dalam Proses Analisis Dampak Lingkungan Hidup dan Izin Lingkungan. 


\section{Wahyu Nugroho, Ida Nurlinda, Bambang Daru Nugroho, Imamulhadi}

Isi pokok dalam Peraturan Menteri tersebut terdapat dalam pasal 4, yakni: Pedoman keterlibatan masyarakat dalam proses Analisis Mengenai Dampak Lingkungan Hidup dan izin lingkungan sebagaimana dimaksud dalam pasal 2 memuat: a. pendahuluan; b. tata cara pengikutsertaan masyarakat dalam proses analisis mengenai dampak lingkungan hidup; dan c.tata cara pengikutsertaan masyarakat dalam proses izin lingkungan.

Apabila dicermati, isi Peraturan Menteri tersebut masih bersifat general, bukan ketentuan yang bersifat teknis operasional terkait terkait dengan tata cara pengikutsertaan masyarakat dalam proses analisis mengenai dampak lingkungan dan izin lingkungan. Tata caranya yang seperti apa dan siapa penanggungjawab dari peran serta masyarakat semestinya diatur dalam peraturan ini. Karena Peraturan Menteri Lingkungan Hidup sebagai kewenangan sektoral di bidang instrumen perizinan lingkungan hidup dan merupakan turunan dari peraturan pemerintah yang semestinya lebih teknis operasional, sehingga tidak bersifat norma umum yang membutuhkan teknis operasional. ${ }^{23}$

\section{Posisi Kasus Terbitnya Keputusan TUN tentang Izin Lingkungan}

Lokasi instrumen perizinan lingkungan untuk kegiatan pertambangan semen di Kabupaten Rembang, yang terbentang kawasan Pegunungan Kendeng Jawa Tengah hingga Jawa Timur. Penentuan lokasi tersebut setelah mendapatkan penolakan oleh masyarakat Kendeng di Kecamatan Sukolilo Kabupaten Pati. Sehubungan dengan pegunungan kendeng di Rembang, sebelumnya dilakukan kajian oleh banyak pihak, diantaranya Dinas Pertambangan Provinsi Jawa Tengah, Wahana Lingkungan Hidup (WALHI),

23 Dalam hierarkhi peraturan perundang-undangan berdasarkan Undang-Undang Nomor 12 tahun 2011 tentang Pembentukan Peraturan Perundang-undangan, Peraturan Menteri tidak masuk dalam kelompok hierarkhi yang utama sebagaimana dalam Pasal 7 ay at (1), antara lain: UUD 1945, Tap MPR, Undang-Undang/Peraturan Pemerintah Pengganti Undang-Undang (Perppu), Peraturan Pemerintah, Peraturan Presiden, dan Peraturan Daerah Provinsi, Kabupaten/Kota. Adapun Peraturan Menteri masuk dalam kelompok di luar hierarkhi. sebagaimana dinyatakan dalam Pasal 8 ay at (1): "Jenis Peraturan Perundang-undangan selain sebagaimana dimaksud dalam Pasal 7 ay at (1) mencakup peraturan yang ditetapkan oleh Majelis Permusyawaratan Rakyat, Dewan Perwakilan Rakyat, Dewan Perwakilan Daerah, Mahkamah Agung, Mahkamah Konstitusi, Badan Pemeriksa Keuangan, Komisi Yudisial, Bank Indonesia, Menteri, badan, lembaga, atau komisi yang setingkat y ang dibentuk dengan Undang -Undang atau Pemerintah atas perintah Undang-Undang, Dewan Perwakilan Raky at Daerah Provinsi, Gubernur, Dewan Perwakilan Rakyat Daerah Kabupaten/Kota, Bupati/Walikota, Kepala Desa atau yang setingkat". Pengaturan itu diakui keberadaannya dan mempunyai kekuatan hukum yang mengikat sepanjang diperintahkan oleh peraturan perundang-undangan yang lebih ting gi.

346 - Jurnal Cita Hukum. Vol. 5 No. 2, December 2017. P-ISSN: 2356-1440. E-ISSN: 2502-230X 
Optik Hakim Terhadap Objek Sengketa Izin Lingkungan, Kadaluarsa dan Asas Partisipasi Masyarakat Dalam Proses Penerbitan Dokumen Lingkungan Hidup atas Kasus Kendeng

Semarang Caver Association (SCA), Jaringan Masyarakat Peduli Pegunungan Kendeng (JMPPK) Rembang dan Kementerian Lingkungan Hidup dan Kehutanan (KLHK). Adapun obyek dari kajian dan penelitian tersebut mengenai bentang alam karst, air bawah tanah, goa-goa alam, sungai bawah tanah, dan Cekungan Air Tanah (CAT) Watuputih.

Pada tanggal 14 Oktober 2010 PT Semen Gresik (Persero) Tbk sejak tanggal 20 Desember 2012 menjadi PT Semen Indonesia (Persero) Tbk, telah mendapatkan Wilayah Izin Usaha Pertambangan melalui Keputusan Bupati Rembang Nomor 545/68/2010 tentang Pemberian Wilayah Izin Usaha Pertambangan (WIUP) Eksplorasi tras kepada PT Semen Indonesia (Persero) Tbk. Pada tanggal 18 Januari 2011, Bupati Rembang menerbitkan Keputusan Nomor 545/4/2011 tentang Izin Usaha Penambangan Eksplorasi atas nama PT Semen Indonesia (Persero) Tbk. Pada tanggal 18 Nopember 2011, Bupati Rembang menerbitkan Keputusan Nomor 591/040/tahun 2011 tentang Pemberian Izin Lokasi kepada PT Semen Indonesia (Persero) Tbk. Selanjutnya, PT Semen Indonesia (Persero) Tbk sejak 20 Desember 2012 telah melakukan Penyusunan Amdal dan dinyatakan layak pada tanggal 30 April 2012, akhirnya keluarlah Surat Keputusan Gubernur Jaw a Tengah Nomor 660.1/10 tahun 2012 tentang Kelayakan Lingkungan Hidup Rencana Penambangan dan Pembangunan Pabrik Semen oleh PT Semen Indonesia (Persero) Tbk di Kabupaten Rembang Propinsi Jaw a Tengah tertanggal 7 Juni 2012.

Setelah adanya keputusan tersebut, Gubernur Jawa Tengah kembali mengeluarkan Keputusan Nomor 660.1/17 tahun 2012 tentang Izin Lingkungan Kegiatan Penambangan dan Pembangunan Pabrik Semen oleh PT Semen Indonesia (Persero) Tbk di Kabupaten Rembang, Propinsi Jaw a Tengah tanggal 7 Juni 2012. Kegiatan-kegiatan dalam izin tersebut meliputi: penambangan batu kapur, penambangan tanah liat, membangun pabrik dan utilitas, membangun jalan produksi dan membangun jalan tambang.

Pada tanggal 15 Februari 2013, PT. Semen Indonesia (Persero) Tbk, telah memegang Izin Usaha Pertambangan (IUP) produksi melalui Surat Keputusan Bupati Rembang Nomor 545/0230/2013 tentang Pemberian Izin Usaha Penambangan (IUP) produksi batuan tanah liat kepada PT Semen Indonesia (Persero) Tbk. Terakhir, dari serangkaian tahapan terbitnya sejumlah dokumen lingkungan tersebut, yang menjadi obyek gugatan dalam putusan ini adalah Keputusan Gubernur Jaw a Tengah Nomor 660.1/17 tahun 2012 tentang Izin Lingkungan Kegiatan Penambangan dan Pembangunan Pabrik Semen oleh PT Semen Indonesia (Persero) Tbk di Kabupaten Rembang, Propinsi Jawa Tengah tanggal 7 Juni 2012.

Faculty of Sharia and Law UIN Syarif Hidayatullah Jakarta - 347 


\section{Wahyu Nugroho, Ida Nurlinda, Bambang Daru Nugroho, Imamulhadi}

Dalam proses dan kronologi terbitnya berbagai instrumen perizinan tersebut di atas yang dimulai dari bupati hingga gubernur, masyarakat tidak dilibatkan proses-proses tersebut, mulai dari penyusunan, pertimbanganpertimbangan, hingga sosialisasi masyarakat yang akan terkena dampak lingkungan, ekonomi, sosial dan budaya. Terkesan, keputusan-keputusan pejabat TUN tersebut sekedar prasyarat formal untuk memenuhi perundangundangan, melindungi dan memperbolehkan perusahaan semen untuk melakukan kegiatan penambangan semen guna kepentingan investasi, pembangunan ekonomi dan termasuk pendapatan asli daerah. Melalui Camat, sebagai perpanjangan tangan dari Bupati Rembang, membujuk beberapa perwakilan masyarakat sekitar diminta untuk menyatakan setuju terkait dengan proses terbitnya dokumen lingkungan, hingga sosialisasi izin lingkungan, hanya sekedar untuk memenuhi persyaratan formal.

\section{Optik Hakim Terhadap Objek Sengketa Izin Lingkungan dan Penggalian Kebenaran atas Fakta-Fakta di Lapangan Pada Masyarakat Kendeng}

Negara hukum (rule of law/rechtstaat) dengan salah satu karakteristik yang dikatakan oleh Jimly Asshiddiqie adalah adanya Peradilan Tata Usaha Negara. ${ }^{24}$ Peradilan Tata Usaha Negara, sebagai bagian dari kekuasaan kehakiman yang berfungsi menjembatani antara kepentingan negara dengan kepentingan masyarakat, melalui keputusan pejabat tata usaha negara dalam domain eksekutif. Obyek sengketa dalam bentuk keputusan pejabat TUN dalam hal ini adalah izin lingkungan, dan terkait dokumen lingkungan lain (Amdal dan UKL-UPL).

Menurut Pasal 53 Ayat (1) Undang-Undang No. 5 Tahun 1986 tentang Peradilan Tata Usaha Negara, sebagai dasar hukum pengajuan gugatan para penggugat:

${ }^{24}$ Peradilan Tata Usaha Negara disebut oleh Jimly Asshiddiqie merupakan 1 (satu) dari 12 (dua belas) prinsip pokok negara hukum (rechtstaat) sebagai pilar-pilar utama yang menyangga berdiri tegaknya satu negara modern yang disebut sebagai negara hukum (rechtstaat). Penjelasan konkritnya adalah harus terbuka kesempatan bagi tiap-tiap warga negara untuk menggugat keputusan pejabat administrasi negara dan dijalankan putusan hakim tata usaha negara (administrative court) oleh pejabat administrasi negara. PTUN disebut tersendiri dari 12 prinsip pokok negara hukum karena menjamin agar warga negara tidak dizalimi oleh keputusankeputusan para pejabat administrasi negara sebagai pihak yang berkuasa. Keberadaan hakim PTUN itu sendiri harus pula dijamin bebas dan tidak memihak sesuai prinsip independen and impartial judiciary. Lihat: Jimly Asshiddiqie, Konstitusi \& Konstitusionalisme Indonesia, Ed. I, Cet. 2, Jakarta: Sinar Grafika, 2011, h. 130-131.

348 - Jurnal Cita Hukum. Vol. 5 No. 2, December 2017. P-ISSN: 2356-1440. E-ISSN: 2502-230X 
“Orang atau badan hukum perdata yang merasa kepentingannya dirugikan oleh suatu keputusan tata usaha Negara dapat mengajukan gugatan tertulis ke pada pengadilan yang berwenang yang berisi tuntutan agar keputusan ta ta usaha Nega ra yang disengketakan itu dinya takan batal a tau tidak sah dengan a tau tanpa disertai tuntutan ganti rugi dan/a tau direhabilitasi"

Adapun penggugat memenuhi legal standing sebagai pihak yang dirugikan dengan terbitnya Surat Keputusan Gubernur Jawa Tengah No.660.1/17 tahun 2012 tentang Izin Lingkungan, yakni penggugat sebagai bagian dari masyarakat yang tinggal di lokasi izin lingkungan dan terkenda dampaknya. ${ }^{25}$ Selain itu, Yayasan WALHI (Wahana Lingkungan Hidup) sebagai organisasi lingkungan hidup bersama dengan masyarakat aktif melakukan gerakan pelestarian dan kepedulian lingkungan hidup. ${ }^{26}$

Majelis hakim PTUN menerima eksepsi dari Tergugat dan Tergugat Intervensi II dalam konteks tenggang waktu pengajuan gugatan yang terhitung sejak diumumkan izin lingkungan. Paradigma hakim yang positivistik terlihat bahwa obyek sengketa TUN di bidang lingkungan hidup sama dengan sengketa TUN pada umumnya. Dasar yang digunakan sebagaimana dinyatakan dalam Pasal 55 UU No. 5 tahun 1986 tentang Per adilan Tata Usaha

25 Berdasarkan Undang-Undang Nomor 32 tahun 2009 tentang Perlindungan dan Pengelolaan Lingkungan Hidup, terdapat tiga pihak yang mempunyai hak gugat lingkungan hidup, yakni pemerintah, masyarakat, dan organisasi lingkungan hidup. Adapun yang menjadi dasar masy arakat memiliki hak gugat dalam bentuk class action dinyatakan dalam Pasal 91 ay at (1) menyatakan: "Masyarakat berhak mengajukan gugatan perwakilan kelompok untuk kepentingan dirinya sendiri dan/atau untuk kepentingan masyarakat apabila mengalami kerugian akibat pencemaran dan/atau kerusakan lingkungan hidup".

26 WALHI (Wahana Lingkungan Hidup), sebagai salah satu organisasi lingkungan hidup yang memiliki legal standing untuk melakukan gugatan. Sebagai dasar hukumnya dalam Pasal 92 Ayat (1) UU No. 32 tahun 2009, menyatakan: "Dalam rangka pelaksanaan tanggung jawab perlindungan dan pengelolaan lingkungan hidup, organisasi lingkungan hidup berhak mengajukan gugatan untuk kepentingan pelestarian fungsi lingkungan hidup". WALHI telah memenuhi persyaratan sebagaimana dinyatakan dalam Ayat (3), Organisasi lingkungan hidup dapat mengajukan gugatan apabila memenuhi persyaratan: a. berbentuk badan hukum; b. menegaskan di dalam anggaran dasarnya bahwa organisasi tersebut didirikan untuk kepentingan pelestarian fungsi lingkungan hidup; dan c. telah melaksanakan kegiatan nyata sesuai dengan anggaran dasarnya paling singkat 2 (dua) tahun. Yayasan WALHI didirikan berdasarkan Akta Notaris Nomor 05 tanggal 27 Mei 2007, Akta Notaris Arman Lany, SH., mendaftarkan organisasinya berdasarkan Surat Keputusan Menteri Hukum dan Hak Asasi Manusia Nomor C2889.HT.01.02.TH2007, tanggal 10 September 2007 dengan bentuk y ay asan. Sampai saat ini telah memiliki perwakilan 28 Provinsi yang disebut dengan Eksekutif Daerah. WALHI telah melakukan gerakan riil terhadap lingkungan hidup di daerah masing-masing, pelestarian fungsi lingkungan hidup, pemajuan, perlindungan, penegakan, penghormatan terhadap hukum, khususnya lingkungan hidup Indonesia menjadi garda terdepan dalam gerakan organisasi lingkungan hidup di Indonesia. 


\section{Wahyu Nugroho, Ida Nurlinda, Bambang Daru Nugroho, Imamulhadi}

Negara, dimana regulasi tersebut telah dua kali perubahan, yakni UndangUndang Nomor 9 Tahun 2004, dan terakhir Undang-Undang Nomor 51 tahun 2009. Pasal 55 tersebut menyatakan: “Gugatan dapat diajukan hanya dalam tenggang waktu sembilan puluh hari terhitung sejak diterimanya atau diumumkannya Keputusan Badan atau Pejabat Tata Usaha Negara."

Apabila dicermati, pijakan Pasal tersebut sebenarnya menjadi dasar untuk tidak diterimanya gugatan penggugat, dengan alasan bahw a penggugat mengajukan gugatan telah melebihi batas waktu 90 hari. Selain itu, hakim tidak meneropong lebih jauh dalam hal kerugian besar dampak lingkungan yang dialami penggugat di kemudian hari dan metode apa yang digunakan oleh pemerintah untuk mengumumkan izin lingkungan kegiatan penambangan dan pembangunan pabrik semen. Segala apa yang disanggah oleh tergugat dan tergugat intervensi II telah ditafsirkan oleh hakim secara gramatikal, bahkan diterima hanya dengan membaca teks. Pandangan hakim yang positivistik dalam penanganan perkara lingkungan hidup akan dirasa sangat jauh dari keadilan dan kemanfaatan masyarakat, selain kering akan penafsiranpenafsiran hukum yang lebih dalam dan komprehensif maupun faktor-faktor non hukum yang terkandung dipertimbangannya. Padahal, hakim memiliki kewajiban untuk menggali hukum yang hidup dalam masyarakat dan faktafakta yang terjadi di lapangan. ${ }^{27}$

Hukum yang hidup menjelma menjadi hukum lokal atau hukum adat dimana masyarakat kendeng yang mayoritas bekerja sebagai petani atau pekebun telah memiliki pengelolaan tersendiri terhadap lingkungan hidup atas kawasan karst pegunungan Kendeng, sebagai bagian dari kehidupannya dan cekungan air tanah watuputih, dan keadilan yang hidup dalam masyarakat kendeng, yakni akses hak ekonomi, sosial dan budaya serta hak-hak lingkungan untuk tidak boleh dirusak telah diabaikan oleh hakim.

Majelis hakim tingkat pertama dan diperkuat di tingkat banding, menilai bahw a Penggugat tidak memiliki dasar hukum yang sah dengan alasan tidak sesuai dengan Pasal 93 ayat (1) UU No. 32 tahun 2009, yang pada intinya seseorang dapat mengajukan gugatan terhadap izin lingkungan apabila perusahaan yang semestinya wajib amdal, namun tidak memiliki amdal. Sementara hakim di tingkat Peninjauan Kembali Mahkamah Agung, menyanggah dan mementahkan semua dalil, tafsiran, pertimbangan dan

27 Kewajiban hakim dalam menggali hukum yang hidup dalam masyarakat dinyatakan dalam Pasal 5 Ayat (1) UU No. 48 tahun 2009 tentang Kekuasaan Kehakiman, yakni: Hakim dan hakim konstitusi wajib menggali, mengikuti, dan memahami nilai-nilai hukum dan rasa keadilan y ang hidup dalam masyarakat.

350 - Jurnal Cita Hukum. Vol. 5 No. 2, December 2017. P-ISSN: 2356-1440. E-ISSN: 2502-230X 
Optik Hakim Terhadap Objek Sengketa Izin Lingkungan, Kadaluarsa dan Asas Partisipasi Masyarakat Dalam Proses Penerbitan Dokumen Lingkungan Hidup atas Kasus Kendeng

kesimpulan dari hakim tingkat pertama dan banding. Perlu diketahui, bahwa dalam proses Amdal, masyarakat tidak pernah dilibatkan untuk memberikan pertimbangan, penilaian dan pengumuman atas terbitnya Amdal, sehingga Amdal menjadi cacat prosedur terkait keterlibatan masyarakat sekitar dalam proses Amdal dan studi kelayakan kegiatan penambangan pada kawasan Cekungan Air Tanah (CAT), termasuk resiko-resiko apa yang akan terjadi. Hal tersebut mendasarkan kepada Peraturan Menteri Lingkungan Hidup No. 17 tahun 2012 tentang Pedoman Keterlibatan Masyarakat dalam Proses Amdal dan Izin Lingkungan. Proses Amdal tidak mempertimbangkan antara kegiatan penambangan pada kawasan CAT dengan kawasan yang bukan CAT. Selain hal tersebut, dokumen Amdal tidak mencerminkan Asas-asas Umum Pemerintahan yang Baik (AUPB), asas kelestarian, asas kehati-hatian, dan asas kecermatan dalam penyusunan Amdal.

Batas waktu mengajukan gugatan menjadi penyebab putusan tidak dapat diterima. Terkait batas waktu dalam praktik menjadi penafsiran tersendiri bahkan perdebatan diantara hakim Pengadilan Tata Usaha Negara hingga ke tingkat Mahkamah Agung. Pada pengadilan tingkat pertama dan diperkuat di tingkat banding, majelis hakim hanya berpatokan kepada Pasal 55 UU No. 5 tahun 1986 tentang Peradilan Tata Usaha Negara, dan mengabaikan Pasal 89 ayat (1) UU No. 32 tahun 2009 tentang PPLH. ${ }^{28}$ Padahal, obyek sengketa TUN merupakan bidang lingkungan hidup yang memiliki karakter khusus, penghitungannya sejak diketahui adanya pencemaran atau kerusakan lingkungan hidup. Dalam obyek sengketa izin lingkungan, majelis hakim agung Peninjauan Kembali mendasarkan kepada Pasal 89 ayat (1) UU No. 32 tahun 2009 tentang Perlindungan dan Pengelolaan Lingkungan Hidup.

Hakim Agung menafsirkan tenggang waktu pengajuan gugatan dihitung 90 hari sejak diketahui adanya potensi kerusakan dan/atau pencemaran lingkungan akibat penerbitan surat izin lingkungan objek sengketa dari sarana tersebut. Selain itu, dalam pengumuman tidak mencantumkan potensi kerusakan dan/atau pencemaran yang mungkin akan terjadi apabila objek sengketa direalisasikan. Cara mengumumkannya melalui website juga tidak sesuai dengan kondisi masyarakat Kendeng yang mayoritas pekerja

28 Pasal 89 ayat (1) UU No. 32 tahun 2009 tentang Perlindungan dan Pengelolaan Lingkungan Hidup, dapat dikatakan ketentuan lex spesialis dari perkara sengketa tata usaha negara pada umumnya. Dalam kasus ini, hakim tingkat pertama mengabaikan ketentuan tersebut, sehing ga menjadi dasar pertimbangan putusan tidak dapat diterima. Adapun bunyi Pasal tersebut menyatakan: "Tenggat kedaluwarsa untuk mengajukan gugatan ke pengadilan mengikuti tenggang waktu sebagaimana diatur dalam ketentuan Kitab Undang-undang Hukum Perdata dan dihitung sejak diketahui adany a pencemaran dan/atau kerusakan lingkungan hidup".

Faculty of Sharia and Law UIN Syarif Hidayatullah Jakarta - 351 


\section{Wahyu Nugroho, Ida Nurlinda, Bambang Daru Nugroho, Imamulhadi}

petani dan pekebun, tidak ada media untuk mengakses informasi tersebut. Hal ini merupakan suatu strategi pemerintah untuk "sekedar memenuhi syarat formal" atas terbitnya izin yang harus diketahui oleh masyarakat.

Jenis perkara lingkungan hidup yang masuk di pengadilan, dapat dikategorikan menjadi tiga jenis, yakni perkara sengketa administrasi lingkungan, penyelesaiannya di Pengadilan Tata Usaha Negara, sedangkan perkara sengketa perdata lingkungan dan pidana lingkungan hidup di Pengadilan Negeri. Hakim yang memeriksa perkara lingkungan hidup haruslah memiliki sertifikasi penanganan perkara lingkungan hidup. Hal tersebut mendasarkan kepada Surat Keputusan Mahkamah Agung No.134/KMA/SK/IX/2011 yang mengatur tentang Sertifikasi Hakim Perkara Lingkungan Hidup. SK yang diterbitkan 5 September 2011 mengharuskan perkara lingkungan hidup ditangani hakim yang memiliki keahlian di bidang lingkungan hidup yang dibuktikan dengan perolehan sertifikasi dan diangkat oleh Ketua MA.

Dalam praktik di lingkungan Pengadilan Tata Usaha Negara (PTUN), hakim memiliki pemahaman yang berbeda terhadap asas-asas umum pemerintahan yang baik ${ }^{29}$ terhadap izin lingkungan sebagai obyek sengketa lingkungan hidup. Hakim pada tingkat pertama dan tingkat banding dalam memeriksa sengketa keputusan tata usaha negara khusus perkara lingkungan hidup, terjebak dalam pemikiran yang legalistik-positivistik, juga tidak menggali fakta-fakta di lapangan. Obyek sengketa Tata Usaha Negara (TUN) perkara lingkungan hidup tidak dipahami dengan baik oleh hakim, yang kemudian dikaitkan dengan asas-asas umum pemerintahan yang baik hanya secara tekstual, tanpa adanya penggalian lebih dalam atas fakta-fakta yang terjadi di lapangan. Gugatan yang diajukan oleh masyarakat sekitar dan WALHI (Wahana Lingkungan Hidup) di Pengadilan Tata Usaha Negara (PTUN) Semarang, hakim menilai bahw a gugatan yang diajukan telah melebihi tenggang waktu atau daluarsa, dengan batasan maksimal 90 (Sembilan puluh hari kerja) terhitung sejak keputusan tersebut diterbitkan. Selain itu, gugatan

29 Asas-asas Umum Pemerintahan yang Baik (AUPB) sebagai pijakan utama baik penyelenggara Negara (eksekutif) dalam membuat Keputusan Tata Usaha Negara, maupun hakim Pengadilan Tata Usaha Negara ditemukan dalam dua regulasi, pertama, Undang-Undang Nomor 28 tahun 1999 tentang Penyelenggaraan Negara yang Bersih dan Bebas dari Praktik Korupsi, Kolusi dan Nepotisme, Pasal 3 asas-asas umum penyelenggaraan negara meliputi: Asas Kepastian Hukum; Asas Tertib Penyelenggaraan Negara; Asas Kepenting an Umum; Asas Keterbukaan; Asas Proporsionalitas; Asas Profesionalitas; dan Asas Akuntabilitas. Kedua, Undang-Undang Nomor 30 tahun 2014 tentang Administrasi Pemerintahan, Pasal 10 ay at(1) AUPB meliputi: kepastian hukum; kemanfaatan; ketidakberpihakan; kecermatan; tidak menyalahgunakan kewenangan; keterbukaan; kepenting an umum; dan pelay anan yang baik.

352 - Jurnal Cita Hukum. Vol. 5 No. 2, December 2017. P-ISSN: 2356-1440. E-ISSN: 2502-230X 
dinilai prematur dengan alasan upaya administrasi dalam bentuk keberatan masyarakat secara tertulis yang disampaikan kepada Gubernur sebagai bagian dari peran serta masyarakat ternyata belum ditanggapi atau belum mendapatkan jaw aban baik secara lisan maupun tertulis.

Majelis hakim Pengadilan Tata Usaha Negara dalam pertimbangannya menyatakan:

"Menurut hukum bahwa para penggugat dapat dinyatakan telah mengetahui dikaitkan dengan merasa kepentingannya dirugikan dengan diterbitkannya objeksengketa setidak-tidaknya sejak tanggal 22 Juni 2013, saat Wakil Bupati Rembang memberikan penjela san mengani telah terpenuhinya semua izin dari Tergugat II Intervensi, berikut telah disebutkannya izin lingkungan yang dimiliki Tergugat II Intervensi saat dilakukan aca ra silaturahmi yang difasilitasi oleh Camat Gunem di Balai Desa Kecamatan Gunem, dimana Penggugat 1 Joko Prianto hadir saat itu bersama dengan beberapa warga de sa ring 1 (warga yang terkena dampak) sekita r a real lokasi terbitnya izin lingkungan milik Tergugat II Intervensi, namun Sumarno dan Joko Prianto serta beberapa warga tetap melakukan aksi penolakan atas keberadaan PT Semen Indonesia, sedangkan hal tersebut bila disandingkan dengan gugatan para penggugat yang didaftarkan di Kepaniteraan Muda Perkara Pengadilan Tata Usaha Negara Semarang yang terdaftar di bawah Register Perkara Nomor 064/G/2014/PTUN.SMG, tanggal 1 September 2014, sehingga bila dihitung secara kasuis tis dengan mendasarkan ketentuan Pasal 55 berikut penjelas annya Undang-Undang Nomor 5 tahun 1986, telah melebihi tenggang waktu 90 (Sembilan puluh) hari untuk mengajukan gugatan atau ka daluarsa."

Pertimbangan tersebut sebagai dasar untuk memberikan putusan tidak diterimanya gugatan para penggugat, sebagaimana bunyi amar putusan Pengadilan Tata Usaha Negara sebagai berikut:

1. Dalam penundaan: "Menolak permohonan penundaan pelaksanaan surat keputusan objek sengketa."

2. Dalam eksepsi: “Menerima eksepsi tergugat dan tergugat II intervensi tentang tenggang waktu."

3. Dalam pokok sengketa: “Menyatakan gugatan para penggugat tidak diterima (niet onvankelijk verklaard), dan Menghukum para penggugat untuk membayar biaya perkara yang dalam peradilan tingkat pertama diperhitungkan sebesar Rp. 313.500,00 (tiga ratus tiga belas ribu lima ratus rupiah)."

Perjuangan tidak berhenti pada pengadilan tingkat pertama, masyarakat Kendeng sebagai penggugat pada akhirnya mengajukan upaya 


\section{Wahyu Nugroho, Ida Nurlinda, Bambang Daru Nugroho, Imamulhadi}

hukum banding di Pengadilan Tinggi Tata Usaha Negara Surabaya. Adapun pertimbangan Majelis Hakim Pengadilan Tinggi Tata Usaha Negara Surabaya didalam putusannya Nomor 135/B/2015/PT.TUN.SBY, pada halaman 11 berbunyi sebagai berikut:

"Menimbang, bahwa berdasarkan uraian di atas dengan demikian pertimbangan peradilan tingkat pertama telah te pat dan benar. Oleh ka rena itu pertimbangan putusan Pengadilan Tata Usaha Negara Sema rang Nomor 64/G/2014/PTUN.SMG, tanggal 16 April 2015 haruslah dikuatkan, yang untuk singka tnya dan untuk tidak mengulang halyang sama pertimbangan tersebut dianggap dimuat kembali dalam pertimbangan ini dan sebagai bahan pertimbangan dalam memutus perkara ini dalam tingkat banding."

Pertimbangan majelis hakim Pengadilan Tinggi Tata Usaha Negara tersebut pada akhirnya memberikan amar Putusan Bernomor 135/B/2015/PT.TUN.SBY., tanggal 3 Nopember 2015 sebagai berikut:

- Menerima permohonan banding dari para Penggugat/ Pembanding;

- Menguatkan putusan Pengadilan Tata Usaha Negara Semarang Nomor 64/G/2014/PTUN.SMG, tanggal 16 April 2015 yang dimohonkan banding;

- Menghukum para Penggugat/ Pembanding untuk membayar biaya perkara untuk dua tingkat peradilan yang untuk tingkat banding ditetapkan sebesar Rp. 250.000,00 (dua ratus lima puluh ribu rupiah).

Perjalanan hukum masyarakat Kendeng selalu saja mendapatkan petunjuk bukti baru sebagai dasar untuk mengajukan upaya hukum paling akhir dalam sistem peradilan di Indonesia, yakni Peninjauan Kembali (PK) ke Mahkamah Agung. Syarat untuk dapat diajukannya peninjauan kembali adalah adanya suatu novum atau bukti baru. Dalam hal ini, tiket, boarding pass dan surat pernyataan terbang atas nama Joko Prianto (sebagai penggugat) yang disahkan oleh pihak ticketing Garuda Indonesia dengan menggunakan pesawat GA 0507 dari Pontianak tujuan Jakarta pada tanggal 22 Juni 2013 jam 15.00, dengan nomor tiket 126-3970060282. Bukti baru tersebut membuktikan bahwa Joko Prianto tidak menghadiri silaturahmi di balai Desa Kecamatan Gunem pada tanggal 22 Juni 2013. Tiket pesawat yang sebenarnya persoalan sepele, namun dalam hal-hal tertentu justru menjadi senjata paling ampuh untuk memenangkan perkara tingkat paling akhir dalam sistem peradilan Indonesia.

Karakter majelis hakim Peninjauan Kembali dapat dinilai progresif dan menggunakan cara pandang yang holistik tersebut, pada akhirnya 
Optik Hakim Terhadap Objek Sengketa Izin Lingkungan, Kadaluarsa dan Asas Partisipasi Masyarakat Dalam Proses Penerbitan Dokumen Lingkungan Hidup atas Kasus Kendeng

membuahkan hasil para Pemohon Peninjauan Kembali, yakni dikabulkan gugatan untuk seluruhnya, amar putusannya adalah:

1. Mengabulkan Gugatan para Penggugat untuk seluruhnya;

2. Menyatakan batal Surat Keputusan Gubernur Jawa Tengah Nomor 660.1/17 Tahun 2012, tanggal 7 juni 2012, tentang Izin Lingkungan kegiatan penambangan oleh PT Semen Gresik (Persero) Tbk, di Kabupaten Rembang, Provinsi Jaw a Tengah;

3. Mewajibkan kepada tergugat untuk mencabut Surat Keputusan Gubernur Jawa Tengah Nomor 660.1/17 Tahun 2012, Tanggal 7 Juni 2012, tentang Izin Lingkungan di Kabupaten Rembang, Provinsi Jawa Tengah.

4. Menghukum Termohon Peninjauan Kembali untuk membayar biaya perkara dalam semua tingkat pengadilan, yang dalam Peninjauan Kembali ini ditetapkan sebesar Rp. 2.500.000,00 (dua juta lima ratus ribu rupiah).

Suatu hal yang menarik untuk dicermati dalam pertimbanganpertimbangan majelis hakim Peninjauan Kembali adalah para hakim memiliki cara pandang yang holistik terhadap obyek sengketa izin lingkungan dan memiliki tingkat kedalaman untuk menggali fakta-fakta di lapangan yang dihadapi oleh masyarakat kendeng. Selain itu, hampir semua dalil pemohon Peninjauan Kembali dibenarkan oleh hakim. Sebaliknya, hampir semua pertimbangan dan kesimpulan hakim pada tingkat pertama dan tingkat banding dibantah, dinilai keliru atau kekhilafan. Hal tersebut tersebar di berbagai pertimbangan majelis hakim Peninjauan Kembali, diantaranya persoalan masa tenggang pengajuan gugatan, persoalan prematur dalam mengajukan gugatan, legal standing para Penggugat, diabaikannya asas kehathatian dan asas kecermatan, tidak dilibatkannya masyarakat dalam proses penyusunan dokumen lingkungan hidup, dan fakta-fakta lain yang memperkuat dalil Pemohon Peninjauan Kembali.

Kasus ini dapat dijadikan sebagai contoh yang baik dalam kerangka pengembangan kajian hukum lingkungan, hukum administrasi negara, penafsiran atas Asas-asas Umum Pemerintahan yang Baik (AUPB) oleh Pejabat Tata Usaha Negara dan hakim di lingkungan Peradilan Tata Usaha Negara (tingkat pertama), hingga tingkat Hakim Agung, termasuk dapat mengetahui 


\section{Wahyu Nugroho, Ida Nurlinda, Bambang Daru Nugroho, Imamulhadi}

cara berhukum seorang hakim. ${ }^{30}$ Jadi, hakim yang ideal dalam memeriksa perkara lingkungan hidup adalah hakim yang mencintai pelestarian lingkungan hidup, bukan hanya sekedar mengikuti teks pasal kemudian ditafsirkan secara gramatikal, tanpa menggali fakta-fakta kebenaran di lapangan dan mengabaikan keterangan para saksi dan ahli yang dihadirkan.

Hakim Agung (Peninjauan Kembali) mengutip pendapat Badan Geologi Kementerian ESDM yang didasarkan kepada ketentuan Pasal 40 ayat (1) dan (2) Peraturan Pemerintah Nomor 43 tahun 2008 tentang Air Tanah. Pasal tersebut tidak secara eksplisit melarang penambangan pada lokasi Cekungan Air Tanah (CAT), tetapi melarang melakukan kegiatan penambangan dan pengeboran dekat mata air, sedangkan kepala ESDM Provinsi Jawa Tengah (Teguh Dwi Paryono) yang berpendapat tidak ada larangan untuk melakukan penambangan diatas kawasan CAT dan dapat diberikan izin secara khusus. Berlandaskan pada kedua hal pendapat tersebut, hakim Peninjauan Kembali memiliki argumentasi hukum: (1) CAT merupakan suatu wilayah tertentu tempat semua kejadian hidrogeologis seperti proses pengimbuhan, pengaliran, dan pelepasan air tanah berlangsung, sehingga ketentuan Pasal 40 ayat (1) dan (2) mencakup untuk wilayah CAT; dan (2) Asas kehati-hatian dan asas kecermatan dari Asas-asas Umum Pemerintahan yang Baik (AUPB) memberi arah kepada penyelenggara negara agar lebih mengutamakan "menghindari potensi kerusakan/bahaya daripada mengambil manfaat". ${ }^{11}$ Dengan kata lain, untuk mendapatkan manfaat wajib menjauhi potensi kerusakan.

${ }^{30}$ Terdapat dua tokoh terkemuka yang seringkali dikutip oleh Satjipto Rahardjo terkait dengan hakim, yakni pertama, Hakim Agung O.W. Holmes, salah satu eksponen mazhab legal realism, meny atakan bahwa menjalankan hukum bukan hanya soal logika, tetapi juga peng alaman (the life of the law has not been logic, but experience); dan kedua, V an Doorn, sosiolog hukum Belanda mengutarakan secara lain, yakni hukum merupakan skema yang dibuat untuk menata (perilaku) manusia, tetapi manusia itu sendiri cenderung terjatuh di luar skema yang diperuntukkan baginya. Ini disebabkan oleh faktor pengalaman, pendidikan, tradisi, dan lain-lain y ang mempeng aruhi dan membentuk perilakunya. Lihat: Satjipto Rahardjo, Membedah Hukum Progresif, Cet. 2, Jakarta: PT Kompas Media Nusantara, 2007, h. 4.

31 Say a mengapresiasi atas pendapat hakim Peninjauan Kembali tersebut yang menggali lebih dalam makna dibalik teks dan kasus kendeng, hingga menyandarkan kepada kalimat "menghindari potensi kerusakan/bahaya daripada mengambil manfaat." Penulis mengatakan, hal tersebut bukanlah sekedar pendapat hakim, melainkan lebih dari itu, yakni ijtihad hakim. Sebenarny a apabila ditelusuri lebih dalam, kalimat tersebut bersumber dari suatu kaidah fiqhiyy ah, sebagai pedoman dasar dalam istinbath hukum islam. Kaidah fiqhiyyah adalah hukum-hukum y ang berkaitan dengan asas hukum y ang dibangun oleh syari', serta tujuan-tujuan y ang dimaksud dalam pensyari'atannya. Kaidah ini berfungsi untuk memudahkan mujtahid menginstinbathkan hukum yang bersesuaian dengan tujuan syara' dan kemaslahatan manusia. Bunyi dari kaidah 356 - Jurnal Cita Hukum. Vol. 5 No. 2, December 2017. P-ISSN: 2356-1440. E-ISSN: 2502-230X 
Optik Hakim Terhadap Objek Sengketa Izin Lingkungan, Kadaluarsa dan Asas Partisipasi

Majelis hakim Peninjauan Kembali mempertimbangkan dalam penyusunan Amdal perlu memerhatikan AUPB terkait dengan pembatasan dan tata cara penambangan yang dapat mendeskripsikan dan menjamin bahwa kegiatan penambangan tidak mengancam rusaknya sistem akuifer pada kaw asan tersebut dan terancamnya lingkungan hidup masyarakat. Kemudian, tidak layak apabila kegiatan penambangan pada kawasan CAT dilakukan dengan cara yang sama dengan penambangan pada kawasan lain bukan CAT. Pada beberapa bagian dokumen Amdal tidak memperlihakan solusi yang konkret dan tidak tergambar cara alternatif penanggulangannya terhadap masalah kebutuhan warga, diantaranya kekurangan air bersih dan kebutuhan pertanian. Hal ini tidak sejalan dengan peraturan perundang-undangan dan asas kelestarian, asas kehati-hatian, serta asas kecermatan dalam penyusunan Amdal yang dijadikan pendukung utama penerbitan objek sengketa.

\section{Penerapan Hakim Dalam Menafsirkan Ihwal Kadaluwarsa Dan Asas Partisipasi Masyarakat Dalam Proses Penerbitan Dokumen Lingkungan Hidup}

Hakim Pengadilan Tata Usaha Negara menggunakan Asas-asas Umum Pemerintahan yang Baik (AUPB) sebagai dasar untuk memeriksa, mempelajari hingga memberikan pertimbangan dengan sejumlah tafsir hukum yang dimilikinya. Asas-asas umum pemerintahan yang baik salah satunya asas partisipasi masyarakat, yang sangat krusial karena menyangkut dampak sosial dan lingkungan masyarakat sekitar pasca diterbitkannya keputusan Tata Usaha Negara (TUN), dalam konteks ini instrumen perizinan lingkungan hidup, yakni Analisis Mengenai Dampak Lingkungan (Amdal) dan Izin Lingkungan. Dokumen lingkungan tersebut mulai dari awal harus ada partisipasi masyarakat, agar dapat mengakomodasi kepentingan-kepentingan masyarakat sekitar, termasuk multiplier effect dari adanya suatu kegiatan usaha.

Masyarakat Kendeng bersama dengan tim Kementerian Lingkungan Hidup (KLH) pada bulan Juli 2014 telah melakukan kunjungan lapangan di area cekungan air tanah Watuputih, Kecamatan Gunem Kabupaten Rembang.

tersebut dalam bahasa Indonesiany a adalah: "Menolak kerusakan lebih diuta makan daripada mena rik mashlahah, dan apabila berla wanan antara yang mafsadah dan mashlahah, maka yang didahulukan adalah menolak mafsadahnya", atau kaidah singkatnya berbunyi: "Dar'ul mafasid wa jalbul masholikh" (menolak kerusakan dan menarik kemaslahatan). Kaidah tersebut ditemukan dalam kitab al-Asyba' wan-Nadhoir, kary a dari Jalaluddin Abdurrahman As-Suyuthi. Lihat: Muchlis Usman, Kaidah-Kaidah Ushuliyah dan Fighiyah, Pedoman Dasar dalam Instinbath Hukum Islam, Ed. 1, Cet. 4, Jakarta: PT RajaGrafindo Persada, 2002, h. 137 dan h. 143.

Faculty of Sharia and Law UIN Syarif Hidayatullah Jakarta - 357 


\section{Wahyu Nugroho, Ida Nurlinda, Bambang Daru Nugroho, Imamulhadi}

Kunjungan tersebut masyarakat dan tim KLH telah menemukan satu titik ponor yang berada dalam kawasan Izin Usaha Pertambangan (IUP) PT Semen Gresik (Persero) Tbk. Hal tersebut juga dilakukan pada tanggal 12 Agustus 2014 dan menemukan titik ponor. Proses-proses tersebut tidaklah diketahui oleh masyarakat, sementara Izin Usaha Pertambangan (IUP) sudah terbit. Hal tersebut menjadikan dasar bagi masyarakat Kendeng bahw a pejabat tata usaha negara tidak memegang asas partisipasi masyarakat. Dalam melihat perkara ini, hakim tingkat pertama dan tingkat banding tidak melihat perkara secara utuh/holistik, sebaliknya, hakim tingkat Peninjauan Kembali Mahkamah Agung melihatnya secara komprehensif, baik dari sisi aturan (materiil) yang menyangkut objek sengketa di bidang lingkungan hidup, maupun dari sisi prosedur (formil) atas instrumen amdal dan izin lingkungan, serta penggalian atas fakta-fakta di lokasi penambangan oleh PT Semen Gresik.

Berdasarkan peraturan perundang-undangan, sebenarnya tersebar norma yang mengatur partisipasi masyarakat sebagai payung hukum (umbrella lex) dalam konteks pelestarian lingkungan dan masalah perizinan. Dari Undang-Undang No. 32 tahun 2009 tentang Perlindungan dan Pengelolaan Lingkungan Hidup, kemudian menurunkan Peraturan Pemerintah Nomor 27 tahun 2012 tentang Izin Lingkungan, dan terakhir menurunkan lagi ke dalam Peraturan Menteri Negara Lingkungan Hidup Republik Indonesia Nomor 17 tahun 2012 tentang Pedoman Keterlibatan Masyarakat dalam Proses Analisis Dampak Lingkungan Hidup dan Izin Lingkungan.

Fakta yang terjadi adalah pada saat dilakukan silaturahmi oleh Wakil Bupati Rembang di Balai Desa Kecamatan Gunem pada tanggal 22 Juni 2013 tersebut, tidak dimaksudkan secara khusus mengumumkan atau sosialisasi izin lingkungan hanya dengan dasar silaturahmi, kehadiran warga dan daftar absensi peserta. Pelaksanaan silaturahmi tersebut kemudian dijadikan sebagai dasar oleh pemerintah dan dikuatkan oleh majelis hakim tinggi (banding) untuk menafsirkan keterlibatan masyarakat dan telah diketahui oleh masyarakat sebagaimana ketentuan partisipasi masyarakat dalam peraturan perundang-undangan tersebut. Keterlibatan masyarakat semestinya dimaknai dan ditafsirkan "sejak pembuatan dokumen awal hingga keluarnya izin lingkungan". Pelibatan masyarakat merupakan bagian proses pelingkungan, melalui pengumuman dan konsultasi publik. Mencermati kasus ini, dapat dinilai bahwa pelibatan masyarakat hanyalah sekedar bingkai dan dalih saja untuk melegalkan kegiatan usaha yang dibungkus dalam bentuk dokumen amdal dan izin lingkungan, meskipun sebagian besar masyarakat menolak atas kegiatan usaha, namun tidak mematahkan pejabat Tata Usaha Negara untuk mengeluarkan dokumen-dokumen tersebut.

358 - Jurnal Cita Hukum. Vol. 5 No. 2, December 2017. P-ISSN: 2356-1440. E-ISSN: 2502-230X 
Optik Hakim Terhadap Objek Sengketa Izin Lingkungan, Kadaluarsa dan Asas Partisipasi

Ihwal kadaluarsa dalam pengajuan gugatan atas obyek sengketa izin lingkungan hidup menjadi perdebatan diantara para hakim di setiap jenjang dan pejabat tata usaha negara itu sendiri. Batas waktu mengajukan gugatan menjadi penyebab putusan tidak dapat diterima. Terkait batas waktu dalam praktik menjadi penafsiran tersendiri bahkan perdebatan diantara hakim Pengadilan Tata Usaha Negara hingga ke tingkat Mahkamah Agung. Pada pengadilan tingkat pertama dan diperkuat di tingkat Banding, majelis hakim hanya berpatokan kepada Pasal 55 UU No. 5 tahun 1986 tentang Peradilan Tata Usaha Negara, ${ }^{32}$ dan mengabaikan Pasal 89 ayat (1) UU No. 32 tahun 2009 tentang PPLH. ${ }^{33}$ Dua instrumen perizinan lingkungan, yakni Analisis Mengenai Dampak Lingkungan dan Izin Lingkungan secara prosedur tidak memenuhi asas-asas umum pemerintahan y ang baik dan partisipasi masyarakat, sehingga dapat dikatakan cacat prosedur.

Baik penyelenggara negara (Pemerintah Provinsi Jawa Tengah dan Pemerintah Kabupaten Rembang), maupun Hakim Tinggi (tingkat Banding) telah memiliki pemahaman yang sempit dan salah menafsirkan terkait asas partisipasi masyarakat, sebagai perwujudan dari asas keterbukaan yang menjadi bagian dari asas umum pemerintahan yang baik. Hal tersebut ditunjukkan melalui masa tenggang atau batas kadaluw arsa gugatan diajukan yang mengacu pada Pasal 55 UU No. 5 tahun 1986, yakni hingga 90 (Sembilan puluh) hari, sejak keputusan diumumkan tanggal 11 Juni 2012. Padahal, ob yek gugatan TUN di bidang lingkungan hidup berlaku UU No. 32 tahun 2009 dan Surat Edaran Mahkamah Agung (SEMA) No. 2 tahun 1991 bagian V angka 3, yang pada intinya penghitungan gugatan sejak penggugat mengetahui adanya kerugian dalam bentuk pencemaran atau kerusakan lingkungan hidup. Anehnya lagi, Penggugat I yang bernama Joko Prianto pada saat acara silaturahmi tanggal 22 Juni 2013 dianggap hadir, padahal yang bersangkutan telah melakukan perjalanan melalui pesaw at garuda yang dibuktikan dengan tiket dan boarding pass dari Pontianak ke Jakarta. Dasar yang terakhir itulah sebagai senjata ampuh untuk mengajukan Peninjauan Kembali dan akhirnya dikabulkan oleh Mahkamah Agung untuk seluruhnya, membatalkan Pengadilan Tinggi Tata Usaha Negara Nomor 135/B/2015/PT.TUN.SBY.,

32 Pasal 55 UU No. 5 tahun 1986 tentang Peradilan Tata Usaha Negara meny atakan Gugatan dapat diajukan hanya dalam tenggang waktu sembilan puluh hari terhitung sejak saat diterimanya atau diumumkannya Keputusan Badan atau Pejabat Tata Usaha Negara.

33 Pasal 89 ayat (1) UU No. 32 tahun 2009 menyatakan tenggat kadaluwarsa untuk mengajukan gugatan ke pengadilan mengikuti tenggang waktu sebagaimana diatur dalam ketentuan sebagaimana diatur dalam ketentuan Kitab Undang-Undang Hukum Perdata dan dihitung sejak dketahui adany a pencemaran dan/atau kerusakan lingkung an hidup.

Faculty of Sharia and Law UIN Syarif Hidayatullah Jakarta - 359 


\section{Wahyu Nugroho, Ida Nurlinda, Bambang Daru Nugroho, Imamulhadi}

tanggal 3 November 2015 yang menguatkan Putusan Pengadilan Tata Usaha Negara Semarang Nomor 064/G/2014/PTUN.SMG, tanggal 16 April 2015, menyatakan batal Surat Keputusan Gubernur Jaw a Tengah No. 660.1/17 Tahun 2012, tanggal 7 Juni 2012 tentang izin lingkungan kegiatan penambangan oleh PT Semen Gresik (Persero) Tbk, di Kabupaten Rembang Provinsi Jawa Tengah.

\section{Kesimpulan}

Dari uraian pembahasan dan analisis tersebut di atas, dapat disimpulkan bahwa, Pertama, optik hakim terhadap objek sengketa izin lingkungan dan penggalian kebenaran atas fakta-fakta di lapangan pada masyarakat kendeng pada tingkat pertama dan tingkat banding terlihat hanya menggunakan cara pandang berpikir logika semata, memahami objek gugatan TUN biasa sama dengan objek gugatan TUN di bidang lingkungan hidup, sehingga mengabaikan Asas-asas Umum Pemerintahan yang Baik (AUPB), asas kelestarian, asas kehati-hatian, dan asas kecermatan dalam penyusunan amdal sebagai dasar diterbitkannya objek gugatan TUN dalam bentuk izin lingkungan. Sementara Hakim Agung di tingkat Peninjauan Kembali memandang sebaliknya, optik yang holistik dengan memerhatikan dampak lingkungan yang terjadi di kemudian hari, lalu mendasarkan pada Pasal 89 ayat (1) UU No. 32 tahun 2009 tentang PPLH, dan berusaha berijtihad dengan menggali nilai keadilan ekologis melalui fakta-fakta yang ada pada masyarakat kendeng kaw asan Cekungan Air Tanah (CAT).

Kedua, penerapan hakim dalam menafsirkan ihwal kadaluwarsa dan asas partisipasi masyarakat dalam proses penerbitan dokumen lingkungan hidup terlihat adanya perbedaan hakim di tingkat Pertama dan tingkat Banding dengan hakim di tingkat Peninjauan Kembali. Hakim tingkat Pertama dan tingkat Banding telah salah memahami, menafsirkan dan menyimpulkan bahwa kadaluwarsa dalam pengajuan gugatan di bidang lingkungan hidup disamakan dengan obyek gugatan TUN pada umumnya. Sementara di tingkat Peninjauan Kembali menggunakan aturan lingkungan hidup yang bersifat lex spesialis, memiliki karakter khusus, sehingga penghitungan mengajukan gugatan sejak diketahui adanya pencemaran atau kerusakan lingkungan hidup. Hal tersebut berimplikasi kepada keterlibatan masyarakat dalam bentuk sosialisasi oleh pemerintah atas terbitnya izin lingkungan hanya formalitas belaka. Baik dokumen Amdal maupun Izin Lingkungan, secara prosedural tidak terpenuhi asas-asas umum pemerintahan yang baik, asas kelestarian lingkungan, dan asas kehati-hatian. Sedangkan hakim tingkat Peninjauan Kembali Mahkamah Agung menafsirkan keterlibatan masyarakat semestinya 360 - Jurnal Cita Hukum. Vol. 5 No. 2, December 2017. P-ISSN: 2356-1440. E-ISSN: 2502-230X 
Optik Hakim Terhadap Objek Sengketa Izin Lingkungan, Kadaluarsa dan Asas Partisipasi Masyarakat Dalam Proses Penerbitan Dokumen Lingkungan Hidup atas Kasus Kendeng

dimaknai "sejak pembuatan dokumen awal hingga keluarnya izin lingkungan”. Bukti baru (novum) berupa tiket pesawat dan boarding pass Penggugat I menunjukkan baik Pejabat Tata Usaha Negara maupun hakim tingkat Pertama dan tingkat Banding sebagai bentuk kebohongan publik yang nyata-nyata tidak hadir dalam acara sosialisasi izin lingkungan.

\section{Daftar Pustaka}

Amiq, Bachrul, Penerapan Sanksi Administrasi dalam Hukum Lingkungan, Cet. I, Yogyakarta: Laksbang Mediatama, 2013.

Apeldoorn, Van, dalam naskah aslinya berjudul "Inleiding tot de Studie van het Nederlandse Recht", terjemahan oleh Oetarid Sadino, Pengantar Ilmu Hukum, Jakarta: Pradnya Paramita, t.th.

Asshiddiqie, Jimly, Hukum Tata Negara \& Pilar-Pilar Demokrasi, Ed. 2, Cet. 2, Jakarta: Sinar Grafika, 2012.

, Konstitusi \& Konstitusionalisme Indonesia, Ed. I, Cet. 2, Jakarta: Sinar Grafika, 2011.

Bedner, Adriaan, dalam "Pengantar: Akses terhadap Keadilan dan Penanganan Masalah Lingkungan", Akses terhadap Keadilan; Perjuangan Masyarakat Miskin dan Kurang Beruntung untuk Menuntut Hak di Indonesia, Ed. I, Jakarta: HuMa; KITLV-Jakarta; Epistema Institute; Leiden: Van Vollenhoven Institute, 2011.

Hamidi, Jazim, Penerapan Asas-asas Umum Penyelenggaraan Pemerintahan yang layak (AUPB) di Lingkungan Peradilan Administrasi Indonesia, Bandung: Citra Aditya Bakti, 1999.

Helmi, Hukum Perizinan Lingkungan Hidup, Cet. I, Jakarta: Sinar Grafika, 2012.

Manan, Bagir, Beberapa Catatan atas Rancangan Undang-Undang tentang Minyak dan Gas Bumi, Bandung: FH-Unpad, 1999.

Nurlinda, Ida, Monograf Hukum Agraria; Membangun Pluralisme Hukum dalam Kerangka Unifikasi Hukum Agraria, Cet. I, Bandung: Pusat Studi Hukum Lingkungan dan Penataan Ruang Fakultas Hukum Universitas Padjadjaran \& Logoz Publishing, 2014.

Rahardjo, Satjipto, Membedah Hukum Progresif, Cet. 2, Jakarta: PT Kompas Media Nusantara, 2007.

Ridwan HR., Hukum Administrasi Negara, Ed. Cet. 7, Jakarta: PT RajaGrafindo Persada, 2011. 


\section{Wahyu Nugroho, Ida Nurlinda, Bambang Daru Nugroho, Imamulhadi}

Ridwan, Juniarso dan Sodik, Achmad, Hukum Tata Ruang dalam Konsep Kebijakan Otonomi Daerah, Cet. 3, Bandung: Penerbit Nuansa, 2016.

Silalahi, M. Daud, Hukum Lingkungan Dalam Sistem Penegakan Hukum Lingkungan Indonesia, Bandung: Alumni, 2001.

Usman, Muchlis, Kaidah-Kaidah Ushuliyah dan Fiqhiyah, Pedoman Dasar dalam Instinbath Hukum Islam, Ed. 1, Cet. 4, Jakarta: PT RajaGrafindo Persada, 2002.

\section{Putusan Pengadilan}

Putusan Pengadilan Tata Usaha Negara Semarang Nomor 064/G/2014/PTUN.SMG, tanggal 16 April 2015.

Putusan Pengadilan Tinggi Tata Usaha Negara Surabaya Nomor 135/B/2015/PT.TUN.SBY, tanggal 3 November 2015.

Putusan Mahkamah Agung No. 99 PK/TUN/2016, tanggal 5 Oktober 2016.

\section{Peraturan Perundang-undangan}

Undang-Undang No. 5 tahun 1986 jo Undang-Undang Nomor 9 Tahun 2004 jo Undang-Undang Nomor 51 tahun 2009 tentang Peradilan Tata Usaha Negara

Undang-Undang No. 32 tahun 2009 tentang Perlindungan dan Pengelolaan Lingkungan Hidup.

Undang-Undang Nomor 28 tahun 1999 tentang Penyelenggaraan Negara yang Bersih dan Bebas dari Praktik Korupsi, Kolusi dan Nepotisme

Undang-Undang Nomor 30 tahun 2014 tentang Administrasi Pemerintahan

Undang-Undang No. 48 tahun 2009 tentang Kekuasaan Kehakiman

Undang-Undang Nomor 12 tahun 2011 tentang Pembentukan Peraturan Perundang-undangan

Peraturan Pemerintah No. 27 tahun 2012 tentang Izin Lingkungan

Peraturan Menteri Negara Lingkungan Hidup Republik Indonesia Nomor 16 tahun 2012 tentang Pedoman Penyusunan Dokumen Lingkungan Hidup

Peraturan Menteri Negara Lingkungan Hidup Republik Indonesia No. 17 tahun 2012 tentang Pedoman Keterlibatan Masyarakat Dalam Proses Analisis Dampak Lingkungan Hidup dan Izin Lingkungan

362 - Jurnal Cita Hukum. Vol. 5 No. 2, December 2017. P-ISSN: 2356-1440. E-ISSN: 2502-230X 